\title{
Avian Assemblages Differ between Old-Growth and Mature White Pine Forests of Ontario, Canada: A Role for Supercanopy Trees?
}

\section{Différence d'assemblage aviaire entre les forêts matures et les vieilles forêts de Pins blancs en Ontario, Canada : un rôle pour les arbres de très grande taille?}

\author{
David Anthony Kirk ${ }^{1}$, Daniel A. Welsh ${ }^{2}, \underline{\text { James A. Baker }}^{3}, \underline{\text { Ian D. Thompson }}^{2}$ and Myriam Csizy
}

ABSTRACT. We predicted that bird diversity and abundance of some bird species would be higher in old-growth stands than in mature pine stands because of the greater structural diversity in old growth. We also predicted that patch size of stands should be influential. To test these predictions, we modeled counts of 79 bird species from 52 stands in 5 regions in the province of Ontario, Canada in relation to habitat at the local and landscape extents. Neither total species richness nor abundance differed between stand types. No significant difference was found in bird assemblages between stand types using ordination analysis. However, more Neotropical migrants were found in old-growth stands than in mature stands, while the reverse was true for short-distance migrants. Twenty-five species had higher counts in old-growth stands-three significantly so: Brown Creeper Certhia americana, Northern Parula Setophaga americana, and Scarlet Tanager Piranga olivacea. Supercanopy pine $(>60 \mathrm{~cm}$ $\mathrm{dbh}$ ) was a significant $(\mathrm{P}<0.05)$ positive predictor for Black-throated Green Warbler Setophaga virens, Northern Parula, and total species richness, while medium/large pine $(>40 \mathrm{~cm} / \mathrm{dbh})$ was a significant positive predictor for Brown Creeper, Pine Warbler Setophaga pinus, and total species richness. The density of supercanopy and medium/large pine explained a small but significant amount of variation in bird assemblages (1\%), after considering age, other tree variables (9\%), and landscape metrics. Patch size was significant for Evening Grosbeak Coccothraustes vespertinus and total abundance. According to receiver operating characteristic (ROC) thresholds, Brown Creeper required a minimum of 62 stems/ha of medium/large pine. Pileated Woodpecker Dryocopus pileatus and Black-throated Green Warbler required a minimum of 14 and 23 stems/ha of supercanopy pine, respectively. Blackburnian Warbler Setophaga fusca required a minimum stand age of 66 years. Current targets in shelterwood seed cuts for pine appear to be just within range for Brown Creeper-at least for the first cut, but not for subsequent cuts. We recommend that forest management seek to emulate increased old-growth characteristics in a proportion of managed stands that fall within the range of variation expected under natural variation.

RÉSUMÉ. Nous avons prévu que la diversité et l'abondance de certaines espèces d'oiseaux seraient plus grandes dans les vieux peuplements de pins comparativement aux peuplements matures à cause de la plus grande diversité structurale des premiers. Nous avons également prévu que la superficie des peuplements aurait une influence. Pour vérifier ces hypothèses, nous avons modélisé les dénombrements de 79 espèces d'oiseaux dans 52 peuplements de 5 régions de l'Ontario, au Canada, en relation avec l'habitat à l'échelle locale et à celle du paysage. Ni la richesse spécifique totale ni l'abondance n'ont différé entre les types de peuplements. L'assemblage aviaire n'était pas significativement différent entre les types de peuplements, selon une analyse par ordination. Toutefois, un nombre supérieur de migrateurs néotropicaux a été trouvé dans les vieux peuplements, tandis que les migrateurs de courte distance l'emportaient dans les peuplements matures. Vingt-cinq espèces étaient plus abondantes dans les vieux peuplements, dont trois de façon significative : le Grimpereau brun Certhia americana, la Paruline à collier Setophaga americana et le Piranga écarlate Piranga olivacea. Les pins de très grande taille (> $60 \mathrm{~cm} \mathrm{dhp)} \mathrm{représentaient} \mathrm{une} \mathrm{variable}$ explicative positive significative $(\mathrm{p}<0,05)$ pour la Paruline à gorge noire Setophaga virens, la Paruline à collier et la richesse spécifique totale, alors que les pins de moyenne ou grande taille (>40 $\mathrm{cm}$ dhp) représentaient une variable explicative positive significative pour le Grimpereau brun, la Paruline des pins Setophaga pinus et la richesse spécifique totale. La densité des pins de très grande taille et celle des pins de moyenne ou grande taille ont expliqué une faible proportion - mais significative - de la variabilité de l'assemblage aviaire (1\%), après qu'aient été considérés l'âge, d'autres caractéristiques liées aux arbres $(9 \%)$ et des paramètres du paysage. La superficie des peuplements était significative pour le Gros-bec errant Coccothraustes vespertinus

\footnotetext{
${ }^{1}$ Aquila Conservation and Environment Consulting, ${ }^{2}$ Canadian Forest Service, ${ }^{3}$ Ontario Ministry of Natural Resources
}



Sponsored by the Society of Canadian Ornithologists and Bird Studies Canada

Parrainée par la Société des ornithologistes du Canada et Études d'oiseaux Canada

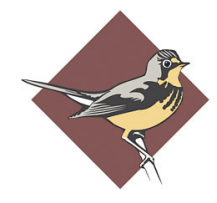

BIRD STUDIESCANADA
ÉTUDES D'OISEAUX CANA 
et l'abondance totale. D' après les seuils ROC, le Grimpereau brun avait besoin d'un minimum de 62 tiges/ha de pins de moyenne ou grande taille, le Grand Pic Dryocopus pileatus et la Paruline à gorge noire recherchaient un minimum de 14 et 23 tiges/ha de pins de très grande taille, respectivement, et la Paruline à gorge orangée Setophaga fusca avait besoin de peuplements âgés d'au moins 66 ans. Les prescriptions actuelles des coupes progressives d'ensemencement pour les pins semblent être tout juste suffisantes pour le Grimpereau brun - pour ce qui est de la première coupe, mais pas pour les coupes subséquentes. Nous recommandons donc que l'aménagement forestier cherche à reproduire les caractéristiques des vieilles forêts dans une proportion de peuplements aménagés qui correspond aux variations attendues dans les conditions de variations naturelles.

Key Words: avian abundance; avian assemblage; avian diversity; forest management; old-growth pine stands; Ontario, Canada; supercanopy pine; white pine

\section{INTRODUCTION}

Globally, primary old forests have been lost at a rapid rate of more than 10 million ha/year for more than 20 years (FAO 2010); related to these losses has been the decline of associated biological diversity (e.g., Secretariat of the Convention on Biological Diversity 2010). For example, the decline of avian species as a result of forest management and the reduction in old forests have been well documented in Scandinavia (e.g., Helle and Jarvinen 1986, Linder and Östlund 1992). While the importance of old-growth forests as critical habitat for various species in western North America has been recognized for more than two decades (e.g., Thomas et al. 1988, Franklin 1989, Ruggiero et al. 1991), it is only in the last 10 to 20 years that the potential importance of eastern old-growth forests to biodiversity conservation has been acknowledged (Bolgiano 1989, Mosseler et al. 2003). Reductions in habitat quality and quantity of old-growth forest have contributed to the rarity and near-extinction of some species (e.g., the endangered Redcockaded Woodpecker Picoides borealis in the southeastern United States (Jackson 1994) and to the presumed extinction of the Ivory-billed Woodpecker Campephilus principalis (Jackson 2002)). However, the only possible example of an avian species that almost became extinct because of loss of old-growth pine forests in Canada is the "old northeastern" subspecies of Red Crossbill (Loxia curvirostra percna), both on the mainland (Dickerman 1987) and in Newfoundland (Environment Canada 2006, but see Benkman 1989 for an alternative view).

Prior to European settlement of the Great Lakes-St. Lawrence region of eastern North America, forests containing red pine (Pinus resinosa Ait.) and white pine (Pinus strobus L.) were common (Frelich and Reich 1996, Rajora et al. 1998). The majority of these historical forests were selectively logged,${ }^{[1]}$ mostly for ship masts and square timber in the 1600s, and for sawn lumber in the early 1800s (Aird 1985, Wray 1986, Barnes 1989). Most of the logged stands were $>200$ years old, with individual trees being 46 to $61 \mathrm{~m}$ in height and 1.2 to $2.1 \mathrm{~m}$ in diameter (Frotheringham 1914). This historical logging, plus a policy of eliminating old growth earlier this century, fire suppression, and, in some areas, fungal disease, have together contributed to the loss and fragmentation of eastern old-growth pine forests, and to the resulting landscape pattern of remnant, isolated stands seen today (Suffling et al. 2003, Thompson et al. 2006). Evidence for significant reductions in red and white pine comes from broad-scale studies (e.g., $>180,000 \mathrm{~km}^{2}$ by Pinto et al. 2008; see also Leadbitter et al. 2002). In Algonquin Park (a $7630-\mathrm{km}^{2}$ provincial park in central Ontario, Canada), pine-dominated stands have declined by $40 \%$. There has also been a reduction of pine content in mixedwoods from 3 to $>8$ pines/ha to $<1$ pine/ha today. The mean diameter of trees has declined from $73.4 \mathrm{~cm}$ to $44.5 \mathrm{~cm}$, hence reducing structure in mixed species stands (Thompson et al. 2006).

Structural features characterizing old growth include: an uneven or multi-aged stand structure, several distinct age cohorts, the average age of dominant species approaching half their longevity (150+ years for most shade-tolerant trees), some old trees being close to their maximum longevity (300+ years), snags and dying trees, downed woody debris in various decay states, and natural regeneration of dominant trees in gaps or on decaying logs (Leverett 1996, Uhlig et al. 2001, Mosseler et al. 2003). Compositional features include: longlived, shade-tolerant tree species and process features such as small-scale gap disturbance; long-term natural rotation for catastrophic/stand-replacing disturbance; minimal evidence of human disturbance; and the final stages of stand development occurring before the stand attains a steady state of gap-phase replacement preceding the next catastrophic disturbance.

One obvious feature in Great Lakes-St. Lawrence old pine forests is the presence of large, supercanopy white pine trees; supercanopy trees are generally trees $\geq 30 \mathrm{~m}$ tall that stand above the main canopy (Bebber et al. 2004). In these forests, the most common natural disturbance was frequent understory fires of moderate intensity, although less frequent overstory, stand-replacing fires also occurred, both of which were often started by lightning (Elkie et al. 2009). Historically, the latter were estimated to have occurred every $1000+$ years (Whitney 1986, Frelich and Lorimer 1991), hence the high probability of old growth developing in Great Lakes-St. Lawrence Region pine forests. Gap-phase disturbance due to windfall was less common.

In Ontario, an estimated $80 \%$ of forest-dwelling vertebrates make use of forest types containing white or red pine, although not necessarily exclusively (Naylor 1994). In the northeastern United States, 68 wildlife species used mature or old-growth 
pine, and for seven of these, mature or old growth was the preferred habitat (DeGraaf and Rudis 1986). Although most bird species that occur in red or white pine forests also occur in other conifers and/or mixedwood forest types, their relative abundance or probability of occurrence may be higher in old pine (Thompson et al. 1995a, Hagan and Grove 1999). For example, in Ontario, some bird species preferring pine seeds (Red Crossbills and White-winged Crossbills Loxia leucoptera (see Benkman 1993, Adkisson 1996) were recorded more often in stands with white pine than in mixedwoods without pine (Thompson et al. 1995a). However, apart from the Pine Warbler Setophaga pinus (Rodewald et al. 1999), no bird species has been specifically identified as being dependent on old-growth or mature pine forests in eastern North America (Haney and Schaadt 1996, Cadman et al. 2007). In pine stands in the southeastern United States (for example, Loblolly Pinus taeda and Short-leaved pine $P$. echinata). Neotropical migrant bird species are often associated with deciduous foliage (though some are attracted to pine); hence the distribution and abundance of foliage are determinants of bird communities (Dickson et al. 1995).

Old pines may contribute to stand structural diversity by providing a supercanopy or large, long-standing snags, or by providing structure within deciduous-dominated stands. Little empirical data exist as to whether historical old-growth red and white pine forests harbored any unique wildlife communities or species (Thompson 2000; see Welsh et al. 1992 concerning invertebrates, and Carleton 2003 on plant diversity) compared to second-growth mature pine forests that currently occupy much of the Great Lakes forest region. Nevertheless, if some bird species are more abundant in oldgrowth pine versus mature pine forests, and if remaining oldgrowth pine forests are lost or further fragmented through timber harvesting, fire, or disease, then it is possible that populations of these species would decline. Such habitatrelated declines have been recorded in Finland, where species preferring virgin Scots pine (Pinus sylvestris) forests have declined as a result of large-scale modern forestry (Helle and Jarvinen 1986, Virkkala 1989). Based on the results of comparative studies of old-growth versus mature forest in other parts of North America, and knowing that plant community composition is similar between mature and old pine stands, it is unlikely that unique bird communities occur in old pine forests. However, certain features of old-growth stands may be important to birds, and relevant thresholds could be developed for forest management (see Betts and Villard 2009).

We were interested in the possible contributions that old pine forests might make to avian species diversity. We made three predictions about the differences between mature and old pine stands based on other avian studies (e.g., Dickson et al. 1995). First, we expected that structural differences (size of trees, density, downed woody debris, snags) would provide additional habitat space-with a consequent greater abundance of some species in old growth compared to mature pine stands - and that there would be no difference in bird species richness. Second, we predicted that large pine trees would be a critical structural feature, and that this would be reflected in model selection and/or in the amount of variation in abundance of some species explained by large pine trees. Finally, we predicted that the landscape matrix of pine stands may influence bird species composition and abundance therein (Brotons et al. 2003).

Forest managers in Ontario usually harvest pine forests using the shelterwood silvicultural system, before the forests reach the old-growth stage. Rather than removing all trees through a single cut, this system removes the original forest gradually using a series of two to four cuts (preparation, regeneration, first removal, and final removal; Pinto 1998) performed at approximately 20 -year intervals. It allows natural (or a mix of natural and artificial) regeneration to become established under the forest canopy (Thompson et al. 1995b). Our results can shed light on the current direction for retaining supercanopy pine trees and structural features that could be manipulated in managed stands to accelerate the development of old growth.

\section{METHODS}

\section{Study area and stand selection}

In the central Ontario study area, red pine and white pine occur in the Mixedwood Plains and Boreal Shield ecozones across seven ecosites (Chambers et al. 1997). An ecosite is the smallest $\left(<100 \mathrm{~m}^{2}\right.$ scale) mappable unit in the hierarchical Ecological Land Classification (ELC) used by the Ontario Ministry of Natural Resources. It represents a relatively consistent set of environmental factors (geology, soils) and vegetation characteristics.

We used a pre-existing database of bird point counts composed of Forest Bird Monitoring Program surveys (Welsh 1995) and bird survey information from the Canadian Wildlife Service and the Ontario Ministry of Natural Resources. Thus the sites were not selected randomly, and coverage of pine stand types varied by region. We entered the GPS coordinates from the bird survey sites into GIS software (GIS-Based Ranking System for Pine (GRASP)) that provided a spatial map of most pine stands in continuously forested parts of eastern and western Ontario (Baldwin et al. 1994). We first converted the data into arc files using ArcView (ESRI 1999) which enabled us to identify point counts located in red or white pine stands, and then to preselect these data. GRASP identified, as mature and old-growth pine stands, all forests that were at least $10 \%$ white pine and/or red pine and at least 50 years old. And it allowed us to classify stands as in pine, close (within $1 \mathrm{~km}$ ) to pine stands, and not pine. 
In a few cases, bird point count sites known by ground-truthing to be in pine were not selected by the GIS software. We assumed this was because of: (1) errors in GPS locations, (2) the projection used in GIS, or (3) the stands not being entered into the database. To verify stand composition, we crosschecked these problematic stands using the Ontario Forest Resource Inventory (FRI). Our final database consisted of 52 forest stands from five areas: Temagami $(\mathrm{N}=18)$, northwestern Ontario $(\mathrm{N}=17)$, Algonquin $(\mathrm{N}=10)$, eastern Ontario $(\mathrm{N}=4)$, and Gogama $(\mathrm{N}=3)$ (Fig. 1). Five to ten point count stations were conducted in each stand but because some stands had no associated vegetation information, the total number of point count stations included in the study was 132 .

Fig. 1. Map of pine stand locations in five regions in the province of Ontario, Canada: Algonquin, Eastern, Gogama, Northwestern, and Temagami.

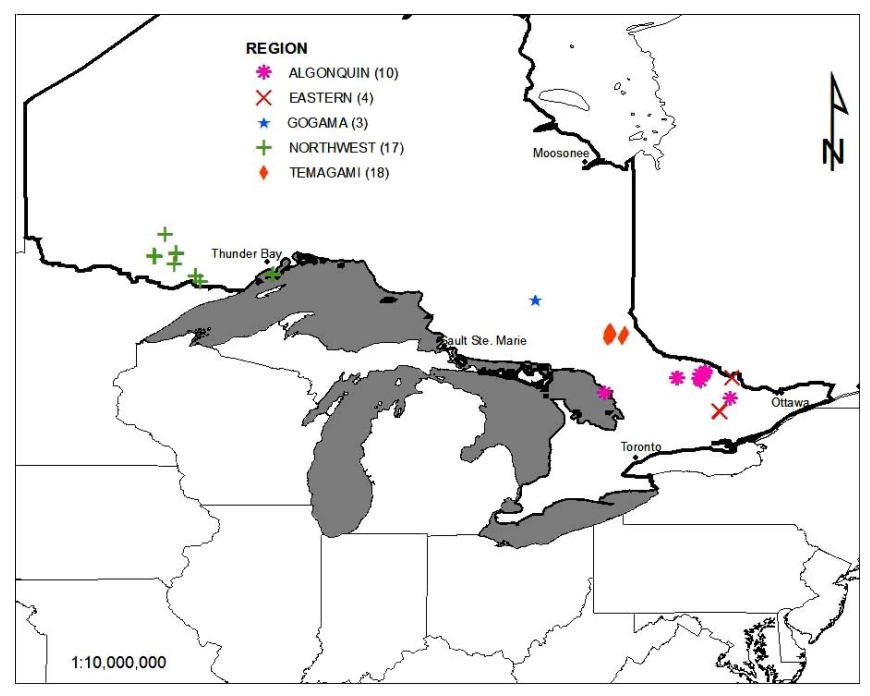

While we attempted to characterize the range of ecosites in each region, inevitably coverage varied because of the selection criteria and the resultant differences in sample sizes. In Temagami and northwestern Ontario, we believe that complete coverage of ecosites dominated by white and red pine was achieved, whereas in Algonquin coverage was incomplete. Few stands from Gogama and eastern Ontario could be included because so few mature and old-growth pine stands occurred there.

\section{Avian surveys}

For point counts, we selected stands from the FRI representing a range of forest types and stand ages. All of the older stands were of fire origin and had incurred very limited harvesting, especially the Temagami stands; younger stands had been harvested in some cases. However, we lacked detailed temporal information on the history of stands in relation to harvesting or natural disturbance. Within each stand, observers flagged a predetermined compass line (from aerial photographs) along which five stations were located, $250 \mathrm{~m}$ apart and $>200 \mathrm{~m}$ from any edge (Ralph et al. 1995). All counts were done between May 25 and July 7, which is the recommended period for breeding bird surveys in Ontario (Welsh 1995). Counts were "unlimited" distance or effectively $200 \mathrm{~m}$ for most forest bird species (see below regarding approaches to deal with potential double counting) and were carried out for a 10-minute period, which was the Forest Bird Monitoring Program's standard at the time (Welsh 1995). To account for changes in song frequency over the breeding cycle, all stations were visited twice: once in late May/early June, and again in mid-late June or early July. Moreover, to reduce possible bias due to diurnal variation in song frequency, we reversed the order in which stations were surveyed on the second visit. We did not correct for species detectability because methods such as double observer approach (Nichols et al. 2000) or the removal method (Farnsworth et al. 2002), had not been developed at the time of our study (see also Johnson 2008, Dawson and Efford 2009).

All singing territorial male songbirds were originally recorded as two individuals (Welsh 1995), which assumes that males are mated. Because this may not be a valid assumption (Bibby et al. 2000), we corrected all of the survey information by dividing counts by two and then rounding up to whole integers. For species that hold group territories (e.g., pine siskin, crossbills, and grosbeaks), this approach could be biased because counts could represent a singing male (counted as two) or two flyovers associated with the stand. We took the maximum count for each bird species from the two visits to each station (Bibby et al. 2000) and then summed counts for all bird species for the five stations in each stand.

Point counts are best suited for counting diurnally active, territorial, forest songbirds that sing or call consistently (Welsh 1995). Species with large home ranges (e.g., raptors, corvids) detected from multiple sites are generally excluded from analyses to minimize statistical dependency (see Kirk and Hobson 2001). However, detectability biases also arise for other species with loud songs, or for some other largebodied birds such as cavity users. Nevertheless, because many species in the latter guild respond to old-growth features, we have included them here. Double counting of large-bodied species (e.g., Pileated Woodpecker) within the same stand was avoided by omitting individuals detected from multiple locations. We believe that the possible bias of double-counting some individuals at some sites is probably counteracted by missing them at other sites (D. A. Welsh, personal observation). Therefore we retained cavity users, raptors, and corvids in our analyses, but omitted nocturnal, crepuscular species, and waterbird species.

In eastern Ontario, Forest Bird Monitoring Program surveys were done by experienced volunteers and contracted Forest 
Bird Monitoring Program recorders, while surveys in Algonquin, Gogama, northwestern Ontario, and Temagami were conducted by Canadian Wildlife Service personnel and contractors. All observers were tested to ensure a common minimum standard of expertise.

The Canadian Wildlife Service point count surveys and the Forest Bird Monitoring Program database differed in that the latter contained counts from multiple years, whereas most contracted surveys were from single years. Thus we selected a single year (the first year of observations) for inclusion. Most $(75 \%)$ of the surveys were carried out in 1989 , but some were done in 1990 (2), 1991 (7), 1992 (2), 1993 (2), and 1996 (1). Because only 14 stands had multiyear data, samples sizes were too small to test for a year effect.

\section{Vegetation features}

Tree density is probably one of the most important response variables for birds in closed-canopy forests, and is strongly correlated with vertical stand structure and shrub density (Hunter 1989). It is also the main component manipulated by forest management. Provided site differences are taken into account, tree size is correlated with age and has been routinely used as a forest descriptor in Ontario (e.g., Plonski 1981). For white pine, tree size (diameter at breast height $(\mathrm{dbh})$ ) is correlated with age until about 250 years, after which the relationship disappears (Guyette and Dey 1995).

To quantify density of woody species by diameter size class (represented by both no. stems/ha and basal area/ha) we used the point-distance-nearest-neighbor method (Batcheler 1973, 1975), which is comparable in accuracy to the prism method commonly used by foresters (Thompson et al. 2007). Sampling was carried out in the same year as the bird counts, $20 \mathrm{~m}$ from each side of the flagged line used for bird surveys, and $100 \mathrm{~m}$ before and $100 \mathrm{~m}$ after each station. Twenty such points were sampled for each station, totaling 100 points and 300 trees or less per stand. These data were then used to estimate tree densities by species and size class.

To reduce the number of variables included in models, we used only those live tree variables that were most important in characterizing old-growth compared to younger stands and those managed as wildlife trees by managers of Great LakesSt. Lawrence forests (Pinto 1998). We combined the density of all red pine and white pine trees $>60 \mathrm{~cm}$ dbh as supercanopy trees and all pines 38 to $60 \mathrm{~cm}$ dbh into a medium/large pine category. We then computed the basal area of all nonpine conifer trees, the basal area of all deciduous trees, and the density of mast trees (American beech Fagus americanus, oaks Quercus spp., American basswood Tilia americana, ironwood Ostrya virginiana, and black cherry Prunus serotina; see Table 1) from the stem densities.

Because the classification of forest ecosites differs regionally, we were unable to use the detailed ecosite information. Instead, we devised the following classification: (1) pine mixedwoods $=$ stands that were $\geq 30 \%$ pine by basal area; (2) pine-conifer mixedwoods $=$ stands with $\geq 30 \%$ conifer basal area; (3) pinedeciduous mixedwoods $=$ stands with $\geq 30 \%$ deciduous tree basal area; and (4) all other stands were considered white pine. In a few cases, stands had $\geq 30 \%$ nonpine conifer and $\geq 30 \%$ deciduous by basal area so we assigned those stands to the class that had the higher percentage basal area. We used the Ontario Ministry of Natural Resources' (2003) definition of $>130$ years old (range 134 to 263 years) to classify pine stands as old growth, and the definition of $<130$ years old to classify pine stands as mature (range 33 to 125 years), based on stand age in the FRI. The Ontario Ministry of Natural Resources (2003) calculated this threshold "by determining the age which the species in question has attained at least $75 \%$ of its maximum potential diameter (for a given site) and made up more than $50 \%$ of the stand basal area." Stand age in the FRI is based on calibration plots of 200-m lines with one plot every 5 to 8 ha for each site type. These calibration plots are used by photo interpreters to estimate the age of stands that do not contain calibration plots (F. Addante, Ontario Ministry of Natural Resources, personal communication).

We obtained the best temporal match between the FRI and bird survey information, and then matched the GPS locations of the point counts with the FRI (M. St. Eloi, Ontario Ministry of Natural Resources, personal communication). The FRI provides information on age, height, stocking, site class, and tree species composition in Ontario forests; we used the FRI for stand age estimates. While we used the most appropriate FRI information available, some errors occur in the FRI (Thompson et al. 2007). For example, one stand in Gogama contained many supercanopy white pine trees but was listed as 35 years old by the FRI, because the dominant lower canopy was comprised of younger trees.

We exported FRI shape files and then derived landscape metrics using Patch Analyst (Elkie et al. 1999). These included mean patch size, total edge, edge density, mean perimeterarea ratio, mean shape index, and mean patch fractal dimension, and these were measured for each stand using the FRI information (1:20,000; approximately $1 \mathrm{~km}$ radius around stands).

We used stands as replicates in our analyses because the pointdistance-nearest-neighbor method only allowed estimates of tree species densities for an entire stand. For several stands, different subplots were sampled (five stations in each subplot) and separate estimates were made of tree densities for each (for example, Greenwood Lake in northwestern Ontario had four lines of bird counts). These were treated as independent samples. If the tree supply information was the same for two subplots, we discarded the smaller of the two subplots (determined from the landscape metrics). 
Table 1. Vegetation features for all pine forests sampled in five regions of Ontario, Canada. Numbers show mean \pm SE, categorical variables (denoted by *, numbers show $\%$ of stands, with $\mathrm{n}$ in parentheses).

\begin{tabular}{|c|c|c|c|c|c|c|c|}
\hline$\underline{\text { Variables }}$ & $\begin{array}{c}\text { Old } \\
\text { growth } \\
\end{array}$ & $\begin{array}{c}\text { Mature } \\
\text { stands }\end{array}$ & $\begin{array}{c}\text { Algonquin } \\
(\mathrm{n}=10)\end{array}$ & Eastern $(n=4)$ & $\begin{array}{c}\text { Gogama } \\
(n=3)\end{array}$ & $\begin{array}{c}\text { Northwest } \\
(\mathrm{n}=17)\end{array}$ & $\begin{array}{c}\text { Temagami } \\
(\mathrm{n}=18)\end{array}$ \\
\hline $\begin{array}{l}\text { Old growth } \\
\text { (>130 years old) }^{*}\end{array}$ & 14.0 & 0.0 & 0.0 & 0.0 & 0.0 & $41.2(7)$ & 38.9 (7) \\
\hline Mature* & 0.0 & 38.0 & $100.0(10)$ & $100.0(4)$ & $100.0(3)$ & $58.8(10)$ & $61.1(11)$ \\
\hline \multicolumn{8}{|l|}{ Tree supply } \\
\hline $\begin{array}{l}\text { Density (no. stems/ha) } \\
\text { supercanopy pine } \\
\text { (SUPCAN) }\end{array}$ & $48.6 \pm 9.8$ & $13.0 \pm 2.4$ & $10.6 \pm 3.2$ & $2.9 \pm 1.5$ & $22.4 \pm 11.5$ & $36.4 \pm 8.8$ & $20.5 \pm 5.6$ \\
\hline $\begin{array}{l}\text { Density (no. stems/ha) } \\
\text { medium/large pine } \\
\text { (MEDLPIN) }\end{array}$ & $28.5 \pm 3.9$ & $41.2 \pm 5.8$ & $69.3 \pm 15.4$ & $13.2 \pm 3.0$ & $9.0 \pm 3.6$ & $39.4 \pm 6.1$ & $28.9 \pm 3.4$ \\
\hline $\begin{array}{l}\text { Basal area, white pine } \\
\text { (WPBA) }\end{array}$ & $24.1 \pm 3.9$ & $12.5 \pm 1.7$ & $19.0 \pm 3.7$ & $4.7 \pm 1.5$ & $8.8 \pm 5.3$ & $18.2 \pm 3.9$ & $14.9 \pm 2.3$ \\
\hline $\begin{array}{l}\text { Basal area, red pine } \\
\text { (RPBA) }\end{array}$ & $3.7 \pm 1.3$ & $8.4 \pm 1.7$ & $11.5 \pm 5.1$ & $12.8 \pm 7.1$ & $2.4 \pm 0.6$ & $7.1 \pm 2.0$ & $4.3 \pm 0.9$ \\
\hline $\begin{array}{l}\text { Basal area, nonpine } \\
\text { conifer (CONBA) }\end{array}$ & $6.6 \pm 1.0$ & $6.8 \pm 1.0$ & $5.9 \pm 2.5$ & $2.2 \pm 1.2$ & $16.1 \pm 0.9$ & $8.0 \pm 0.9$ & $5.4 \pm 0.9$ \\
\hline $\begin{array}{l}\text { Basal area, deciduous } \\
\text { (DECIBA) }\end{array}$ & $5.8 \pm 0.8$ & $8.1 \pm 0.8$ & $7.2 \pm 1.7$ & $14.5 \pm 1.1$ & $7.2 \pm 0.4$ & $4.8 \pm 0.6$ & $8.7 \pm 1.0$ \\
\hline $\begin{array}{l}\text { Density (no. stems/ha), } \\
\text { mast trees (MASTDEN) }\end{array}$ & $0.7 \pm 0.7$ & $4.5 \pm 1.8$ & $4.4 \pm 3.3$ & $27.6 \pm 9.8$ & $0.0 \pm 0.0$ & $0.0 \pm 0.0$ & $1.4 \pm 0.7$ \\
\hline $\begin{array}{l}\text { Total basal area } \\
\text { (TOTALBA) }\end{array}$ & $40.2 \pm 2.9$ & $35.8 \pm 1.8$ & $43.5 \pm 4.5$ & $34.3 \pm 5.8$ & $34.5 \pm 6.2$ & $38.1 \pm 2.6$ & $33.3 \pm 2.1$ \\
\hline \multicolumn{8}{|l|}{ Ecosite } \\
\hline White pine (WHITEP) ${ }^{*}$ & $50.0(7)$ & $28.9(11)$ & $50.0(5)$ & & & $35.3(6)$ & $38.9(7)$ \\
\hline $\begin{array}{l}\text { Mixed red and white } \\
\text { pine (MIXPINE) }\end{array}$ & $28.6(4)$ & $28.9(11)$ & $20.0(2)$ & $50.0(2)$ & & $41.2(7)$ & $22.2(4)$ \\
\hline $\begin{array}{l}\text { Mixed pine and nonpine } \\
\text { conifer (MIXCON)* }\end{array}$ & $14.3(2)$ & $26.3(10)$ & $20.0(2)$ & & $100.0(3)$ & $23.5(4)$ & $16.7(3)$ \\
\hline $\begin{array}{l}\text { Mixed pine and } \\
\text { deciduous (MIXDEC) }\end{array}$ & $7.1(1)$ & $15.8(6)$ & $10.0(1)$ & $50.0(2)$ & & 0.0 & $22.2(4)$ \\
\hline \multicolumn{8}{|l|}{$\begin{array}{l}\text { Resource Inventory } \\
\text { (FRI) }\end{array}$} \\
\hline $\begin{array}{l}\text { Stand age in years } \\
\text { (AGE) }\end{array}$ & $197.3 \pm 12.5$ & $86.0 \pm 4.2$ & $92.3 \pm 6.2$ & $68.3 \pm 5.2$ & $33.0 \pm 0$ & $139.1 \pm 17.6$ & $131.7 \pm 11.8$ \\
\hline Landscape metrics & & & & & & & \\
\hline $\begin{array}{l}\text { Mean patch size (ha) } \\
\text { (MPS) }\end{array}$ & $51.4 \pm 6.4$ & $44.6 \pm 5.9$ & $27.0 \pm 4.5$ & $24.9 \pm 7.2$ & $62.1 \pm 0.0$ & $41.9 \pm 4.7$ & $63.6 \pm 10.9$ \\
\hline
\end{tabular}

\section{Regional variation and spatial autocorrelation}

Our surveys covered a large area; stands in eastern Ontario were more than $1200 \mathrm{~km}$ from those in northwestern Ontario. Species distribution patterns and abundance over such a wide geographical area would be expected to vary naturally because of climate, geology, and underlying historical avian distribution patterns. To test whether there were differences in bird species assemblages among the five regions, we performed nonmetric multidimensional scaling (nMDS based on square-root transformed data) ordination and compared between groups using Analysis of Similarity (ANOSIM, 999 permutations, Clarke and Gorley 2006) and using partial Canonical Correspondence Analysis ( $p \mathrm{CCA})$, while controlling for trend surface variables (ter Braak 1995, ter Braak and Smilauer 2002). For these analyses, we included the 63 bird species that occurred at $>5 \%$ of stands.

Bird species abundance and composition in stands located close together would be expected to be more similar than those further apart, and thus for some stands counts were potentially spatially autocorrelated. We controlled for this in statistical analyses (see Borcard et al. 1992, Bowman et al. 2001). 
Because of the large distance between study areas and consequent longitudinal spread, we chose to account for regional variation by using a trend surface function (Legendre 1993, Legendre and Legendre 1998). We calculated trend surface variables by standardizing latitude and longitude geographic coordinates and calculating second-order and third-order expressions. Usually only a few variables are necessary to describe large-scale spatial patterns, so we used only second-order functions in models (Legendre and Legendre 1998). We first performed Poisson, negative binomial, or multiple linear regression models with backwards elimination of trend surface variables $(\mathrm{P}<0.05)$. We subsequently included only trend surface functions that were significant in models (see Legendre and Legendre 1998). Trend surface functions were included in all models reported, unless stated otherwise.

\section{Avian diversity in old-growth stands compared to mature stands}

We selected species with sufficient information (species that occurred in $20 \%$ or more of stands, $\mathrm{n}=43$ species) for statistical modeling. We also categorized species by migratory guilds (Neotropical migrants, short-distance migrants, nomadic species, and residents (Wong et. al 2003)), because some of these groups are of special concern because of declining populations (Rich et al. 2004).

We modeled bird species' abundance using GLM (Cameron and Trivedi 2001). Because of the high incidence of zeros, a Poisson error was used, and log-link. We used a $\chi^{2}$ test to check for goodness of fit. Where model fit was poor-indicating count overdispersion and/or zero-inflation-we used negative binomial error probabilities. We then inspected the likelihood ratio test of alpha $=0\left(\chi^{2}\right.$ test $)$ to check that this was the appropriate error term. When data were normally distributed (verified using normality test statistics, D'Agostino et al. 1990), we used multiple linear regressions.

We performed three sets of analyses for single species, overall abundance, and species richness. First, we compared counts between old-growth stands and younger stands, and, second, we used the same model but controlled for trend surface functions. Where significant differences occurred in abundance, based on Poisson or negative binomial models, we calculated the incidence rate ratios (IRR; StataCorp 2003) in addition to estimated regression coefficients $\left(e^{b}\right.$, rather than $b$ ). The incidence rate ratios indicate the magnitude of the difference in abundance between two groups, i.e., here, oldgrowth stands and younger stands.

We compared between old-growth stands and younger stands and among regions using ANOSIM and $p$ CCA, as for regional comparisons. For these analyses, we included the 63 bird species that occurred at $>5 \%$ of stands.

\section{Are large pine trees important? For which species?}

To evaluate the importance of large pine trees, we modeled 15 of the most abundant bird species in old-growth stands, as well as species abundance and richness (with and without diurnal raptors and large corvids). For each species, we constructed candidate models (Appendix 1), based on our own a priori knowledge of their habitat associations and on the use of the Avian Life History database of Wildspace (Wong et al. 2003). Because sample sizes were small and because we were most interested in evaluating the importance of supercanopy pine trees, we reduced the number of predictor variables included in models as much as possible. For several species that occur in mixedwoods, we used the same or similar candidate models because they responded to the same suite of predictor variables, at least at the resolution measured. We also developed a priori candidate models for overall abundance and species richness. We included various combinations of predictor variables which were specifically chosen to test interrelationships of tree density, FRI age, modified ecosite type, landscape effects, and trend surface functions. Global models included all variables selected for a particular species and trend surface functions.

To rank alternative models, we used Akaike's Information Criterion ( $\mathrm{AIC}_{\mathrm{c}}$ corrected for small sample size; Anderson et al. 2000, Burnham and Anderson 2002). We calculated AIC, $\triangle \mathrm{AIC}$, and Akaike weights (wi), and then ranked models by their AIC values. We compared models with $\triangle$ AIC $<2$, relatively high Akaike weights $(\geq 10 \%)$, and significant model fit. We included the significance of variables $(\mathrm{P}<0.05)$, and estimated the importance of individual variables, and supercanopy and large pine trees in particular, by summing the Akaike weights for models in which these variables were tested.

To assess the importance of supercanopy/large pine trees at the bird assemblage level, we partitioned the variance unique to supercanopy pine density compared to the basal area of deciduous and nonpine coniferous trees, and compared to the FRI age (for descriptions of variance partitioning see Borcard et al. 1992, Drapeau et al. 2000, Freemark and Kirk 2001, Cushman and McGarigal 2002, and Peres-Neto et al. 2006). We did this using a distance-based redundancy analysis ( $d b$ RDA) with the Hellinger distance measure. Variance partitioning was useful here because correlations among variables can mask their true contribution to overall variance, and we wanted to know the unique contribution of supercanopy pine.

\section{Is patch size of old-growth stands important for birds?}

We also used the same modeling approaches described above to evaluate the importance of patch size of old-growth stands for birds. 
What thresholds of large pine volume are required to predict the probability of bird species presence?

To demonstrate how our results could be used for forest management we explored thresholds in key structural variables using standard procedures for receiver operating characteristic (ROC) curves (Betts and Villard 2009). As an example we focused on species for which large pine trees or stand age had a significant influence. Because these models are based on presence/absence data, and because abundance data at the stand level (as used for other analyses herein) were unsuitable, we used information from the individual point count stations in an events/trials format. We fitted the topranked model from the GLM abundance models in the logistic regression to compute the ROC statistics (area under curve) and thresholds. The species modeled were: Brown Creeper, with density of medium/large pine; Pileated Woodpecker and Black-throated Green Warbler, with density of supercanopy pine; and Blackburnian Warbler, with stand age. Note that these models were for demonstration purposes only.

\section{Software}

For ordinations and other multispecies multivariate statistics we used Primer (version 6, Clarke and Gorley 2006), CANOCO (version 4.5, ter Braak and Smilaeur 2002), and R (R-Core Development Team 2007). We used Stata (StataCorp 2003) and SAS (SAS institute 2008) for single-species analyses.

\section{RESULTS}

We recorded 5013 individuals of 79 avian species in the 52 stands. Sixty-three species occurred in $\geq 5 \%$ of stands and 43 in $\geq 20 \%$ of stands. The most abundant species were: Ovenbird Seiurus aurocapillus (11.9\% of all birds), Red-eyed Vireo Vireo olivaceus (7.3\%), Blackburnian Warbler Setophaga fusca (5.9\%), Swainson's Thrush Catharus ustulatus (5.4\%), and Magnolia Warbler Setophaga magnolia (4.7\%; Fig. 2, and Appendix 2). Ovenbird had the highest mean count, followed by Red-eyed Vireo, Blackburnian Warbler, Swainson's Thrush, and Black-throated Green Warbler Setophaga virens (Fig. 2 and Appendix 2). We recorded Red Crossbills Loxia curvirostra in three stands (counts of 4, 3 , and 1 individuals), which was too few for statistical analyses.

According to the nMDS ordination, there was a strong eastto-west gradient in bird assemblages (Fig. 3). The ANOSIM analysis demonstrated a significant difference among bird assemblages of the five regions; all pairwise comparisons were significant $(\mathrm{P}<0.05)$ except for that between the Algonquin region and the eastern stands.

\section{Avian biodiversity in old-growth stands compared to younger stands}

For the 43 most common species (those occurring at $>20 \%$ of stands), mean counts were higher in old-growth pine than in mature stands for 25 species (Fig. 2 and Appendix 2).
However, this difference was statistically significant for only three species-Brown Creeper Certhia americana, Northern Parula Setophaga americana, and Scarlet Tanager Piranga olivacea-after controlling for trend surface functions (Appendix 2). Brown Creeper was 1.5 times more abundant in old-growth stands than in mature stands, while Northern Parula was 4.6 times more abundant and Scarlet Tanager was 2.7 times more abundant. Two species were recorded only in old-growth (Orange-crowned Warbler Oreothlypis celata and Wood Thrush Hylocicla mustelina), but both occurred only at single sites. Counts of two species (Black-capped Chickadee Poecile atricapillus and Chipping Sparrow Spizella passerina) were significantly higher in mature stands than in old-growth stands. When the trend surface function was omitted, Brown Creeper and Northern Parula were still significantly more abundant in old-growth stands, but results for the other species were no longer significant.

Fig. 2. Mean abundance of 43 bird species ( $>20 \%$ of stands) in old-growth stands ( $>130$ years old) and mature stands ( $<130$ years old), and the number of stands in which they were observed. Species codes are in Appendix 2.




Fig. 3. Nonmetric multidimensional scaling plot of pine stands showing regions. Species with Pearson correlations of $>0.45$ with axes: bhco (Brown-headed Cowbird); eawp (Eastern Wood-pewee); gcfl (Great-crested Flycatcher); heth (Hermit Thrush); lefl (Least Flycatcher); mawa (Magnolia Warbler); mowa (Mourning Warbler); nawa (Nashville Warbler); npwa (Northern Parula Warbler); oven (Ovenbird); rbgr (Rose-breasted Grosbeak); rbnu (Redbreasted Nuthatch); swth (Swainson's Thrush); veer (Veery); wiwr (Winter Wren); wtsp (White-throated Sparrow). Focal species: blbw (Blackburnian Warbler); brcr (Brown Creeper); btnw (Black-throated Green Warbler); evgr (Evening Grosbeak); piwa (Pine Warbler); piwo (Pileated Woodpecker); recr (Red Crossbill).

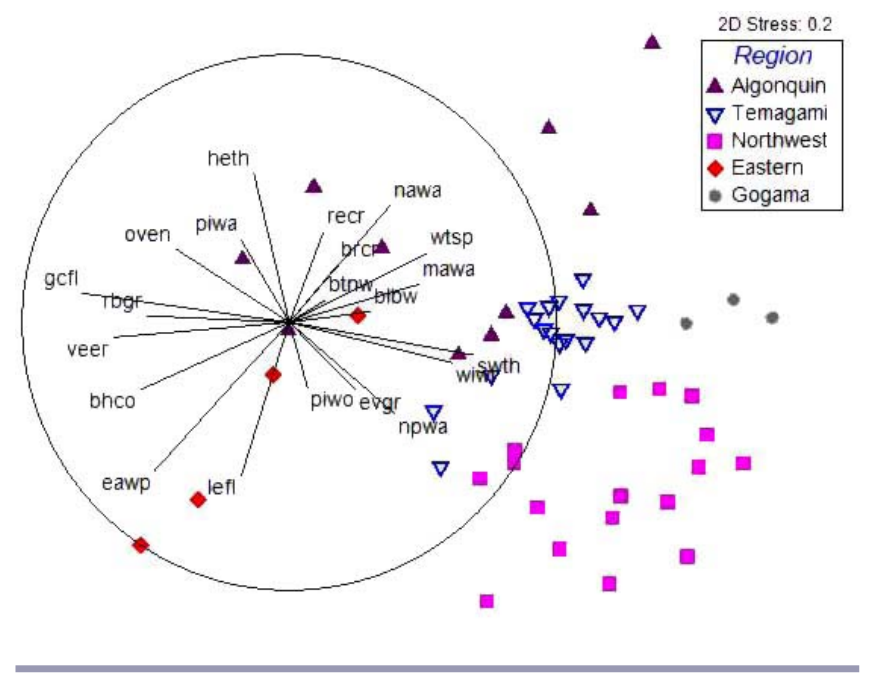

We found no difference in species richness or overall avian abundance between old-growth stands and mature stands. Moreover, no significant difference was found in bird assemblages between old-growth stands and younger stands, according to an ANOSIM comparison of the groups in nMDS (Fig. 4); and, bird assemblages (beta diversity) in CCA were not significantly different between stand types after controlling for trend surface variables $(\mathrm{F}=1.014, \mathrm{P}>0.1)$. However, Neotropical migrants were significantly more abundant in old-growth stands, whereas short-distance migrants were more abundant in mature stands (Appendix 2).

\section{Importance of large pine trees for birds}

Generally, model fit (how well the candidate models fit the bird species data) was good for individual species-except for the Winter Wren Troglodytes hiemalis, for which the global model was best; and Blackburnian Warbler, Brown Creeper, and Golden-crowned Kinglet Regulus satrapa, for which the global model was second best (Table 2). Supercanopy pine $(>60 \mathrm{~cm} \mathrm{dbh})$ was a significant $(\mathrm{P}<0.05)$ positive predictor for Black-throated Green Warbler Setophaga virens, Northern Parula, and total species richness, while medium/large pine (>40 cm/dbh) was a significant positive predictor for Brown Creeper, Pine Warbler Setophaga pinus, and total species richness. The only species for which large pine (supercanopy pine) was a significant negative predictor was the Swainson's Thrush Catharus ustulatus.

Fig. 4. Nonmetric multidimensional scaling plot of pine stands showing old-growth stands and mature stands. Species with Pearson correlations of $>0.45$ with axes: bhco (Brown-headed Cowbird); eawp (Eastern Wood-pewee); gcfl (Great-crested Flycatcher); heth (Hermit Thrush); lefl (Least Flycatcher); mawa (Magnolia Warbler); mowa (Mourning Warbler); nawa (Nashville Warbler); npwa (Northern Parula Warbler); oven (Ovenbird); rbgr (Rosebreasted Grosbeak); rbnu (Red-breasted Nuthatch); swth (Swainson's Thrush); veer (Veery); wiwr (Winter Wren); wtsp (White-throated Sparrow). Focal species: blbw (Blackburnian Warbler); brcr (Brown Creeper); btnw (Black-throated Green Warbler); evgr (Evening Grosbeak); piwa (Pine Warbler); piwo (Pileated Woodpecker); recr (Red Crossbill).



According to summed Akaike weights, density of supercanopy pine was the most important variable in models for Blackburnian Warbler, Pine Warbler, Pileated Woodpecker Dryocopus pileatus, and Swainson's Thrush, and it was the second-most important variable for Blue-headed Vireo Vireo solitarius, Northern Parula, and overall species richness (second equal with ecosite; Tables 2 and 3). However, results for Blackburnian Warbler were difficult to interpret because Akaike weights were similar for several variables, probably because some of these variables were correlated (e.g., conifer basal area, total basal area, and FRI age). In the case of Pine Warbler, the FRI age was equally as important as supercanopy 
Table 2. Model selection results for old-growth-pine-associated bird species. (See Table 1 for predictor variable acronyms). Pine variables are in italics. Significant $(\mathrm{P}<0.05)$ variables are in bold with asterisks.

\begin{tabular}{|c|c|c|c|c|c|c|}
\hline Species/measure & $\begin{array}{c}\text { Minimum } \\
\mathrm{AIC}^{\dagger} \\
\end{array}$ & Model $^{\ddagger}$ & $2 \mathrm{LL}^{\S}$ & $\mathrm{K}^{\prime}$ & $\mathrm{AIC}^{\mathrm{II}}$ & $\mathrm{Wi}^{\#}$ \\
\hline \multirow[t]{2}{*}{ Black-and-white Warbler } & 208.16 & $\begin{array}{l}\text { Model } 1(+ \text { conba, +deciba*, +age*, + } \\
\left.\text { ecosite, }- \text { lat }^{2}\right)\end{array}$ & -97.08 & 7 & 0.00 & 0.49 \\
\hline & & $\begin{array}{l}\text { Model } 2(- \text { supcan },+ \text { conba, +deciba, }+ \\
\left.\text { age* }+ \text { mps, } \text { lat }^{2}\right)\end{array}$ & -96.46 & 8 & 0.76 & 0.33 \\
\hline \multirow[t]{2}{*}{ Blackburnian Warbler } & 274.64 & $\begin{array}{l}\text { Model } 1(+ \text { supcan, -conba, -totalba*, + } \\
\left.\text { age, -lat } \mathbf{2}^{*}\right)\end{array}$ & -130.32 & 7 & 0.00 & 0.55 \\
\hline & &  & -126.68 & 11 & 0.71 & 0.39 \\
\hline \multirow[t]{4}{*}{ Blue-headed Vireo } & 191.54 & $\begin{array}{l}\text { Model } 1 \text { (+medlpin, age }+,+ \text { ecosite, }+ \\
\text { latcorr, +lgcorr) }\end{array}$ & -88.77 & 7 & 0.00 & 0.28 \\
\hline & & $\begin{array}{l}\text { Model } 2 \text { (+supcan, +medlpin, -age, }+ \\
\text { ecosite, +latcorr*, +lgcorr*) }\end{array}$ & -88.04 & 8 & 0.54 & 0.22 \\
\hline & & $\begin{array}{l}\text { Model } 3 \text { (+supcan, -conba, -age, }+ \\
\text { ecosite, +mps, +latcorr*, +lgcorr*) }\end{array}$ & -88.17 & 8 & 0.79 & 0.19 \\
\hline & & $\begin{array}{l}\text { Model } 4 \text { (+supcan, +conba, -totalba, - } \\
\text { age, +latcorr*, +lgcorr*) }\end{array}$ & -88.21 & 8 & 0.88 & 0.18 \\
\hline \multirow[t]{2}{*}{ Brown Creeper } & 177.39 & $\begin{array}{l}\text { Model } 1 \text { (+medlpin, +conba, +age*, - } \\
\text { mps) }\end{array}$ & -81.70 & 7 & 0.00 & 0.44 \\
\hline & & $\begin{array}{l}\text { Global }(+ \text { supcan },+ \text { medlpin } *,+ \text { conba, }- \\
\left.\text { totalba, +age*, -ecosite*, -mps, -lat }{ }^{2}\right)\end{array}$ & -79.06 & 10 & 0.73 & 0.31 \\
\hline \multirow[t]{2}{*}{$\begin{array}{l}\text { Black-throated Green } \\
\text { Warbler }\end{array}$} & 274.72 & $\begin{array}{l}\text { Model } 1(+ \text { supcan*, +conba, }- \\
\left.\text { totalba*, +ecosite, }-\lg ^{2},- \text {-lgcorr }\right)\end{array}$ & -129.36 & 8 & 0.00 & 0.44 \\
\hline & & $\begin{array}{l}\text { Model } 2(+ \text { conba, }+ \text { deciba, }+ \text { age } *,+ \\
\left.\text { ecosite, }- \text { - }^{2} *,- \text { lgcorr }\right)\end{array}$ & -129.94 & 8 & 1.16 & 0.25 \\
\hline Evening Grosbeak & 118.51 & $\begin{array}{l}\text { Model } 1 \text { (-conba, -deciba, +age, }+ \\
\text { ecosite, +mps*, -lglat*) }\end{array}$ & -51.26 & 8 & 0.00 & 0.49 \\
\hline Golden-crowned Kinglet & 193.19 & $\begin{array}{l}\text { Model } 1 \text { (+conba*, -totalba, -age, - } \\
\text { ecosite*, +lglat*) }\end{array}$ & -89.60 & 7 & 0.00 & 0.59 \\
\hline \multirow[t]{2}{*}{ Least Flycatcher } & 196.46 & $\begin{array}{l}\text { Model } 1 \text { (+deciba*, -totalba, +age*,+ } \\
\text { ecosite*, +latcorr*, +lgcorr*, +lg2*) }\end{array}$ & -89.23 & 9 & 0.00 & 0.49 \\
\hline & & $\begin{array}{l}\text { Model } 2\left(- \text { supcan },+ \text { deciba* }{ }^{*},+ \text { age } *,+\right. \\
\text { latcorr*, }+ \text { lgcorr*, }+\lg 2 *)\end{array}$ & -90.87 & 8 & 1.27 & 0.26 \\
\hline \multirow[t]{3}{*}{ Northern Parula } & 71.44 & $\begin{array}{l}\text { Model } 1 \text { (+conba*, -deciba, -ecosite*, - } \\
\text { lgcorr*) }\end{array}$ & -29.72 & 6 & 0.00 & 0.35 \\
\hline & & $\begin{array}{l}\text { Model } 2 \text { (+supcan*, +conba, -totalba, - } \\
\text { age, -lgcorr) }\end{array}$ & -29.03 & 7 & 0.61 & 0.26 \\
\hline & & $\begin{array}{l}\text { Model } 3 \text { (+supcan, -medlpin, -totalba, - } \\
\text { age, -lgcorr) }\end{array}$ & & 7 & 1.80 & 0.14 \\
\hline \multirow[t]{5}{*}{ Pine Warbler } & 212.02 & $\begin{array}{l}\text { Model } 1(+ \text { medlpin, +age, -ecosite, - } \\
\left.\text { latcorr*, }^{*} \text { lat }^{2} *\right)\end{array}$ & -99.01 & 7 & 0.00 & 0.24 \\
\hline & & $\begin{array}{l}\text { Model } 2(- \text { supcan, +age*, +mps, - } \\
\left.\text { latcorr*, - } \text { lat }^{2 *}\right)\end{array}$ & -99.08 & 7 & 0.13 & 0.22 \\
\hline & & $\begin{array}{l}\text { Global (+supcan, +medlpin*, - } \\
\text { totalba, +age, -ecosite, +mps, - } \\
\left.\text { latcorr*, -lat }^{2} *\right)\end{array}$ & -96.45 & 10 & 0.87 & 0.15 \\
\hline & & $\begin{array}{l}\text { Model } 3(- \text { supcan, -totalba, +age*, - } \\
\left.\text { latcorr*, - -lat }{ }^{2 *}\right)\end{array}$ & -99.45 & 7 & 0.88 & 0.15 \\
\hline & & $\begin{array}{l}\text { Model } 4 \text { (+supcan, +medlpin, - } \\
\left.\text { ecosite, -latcorr*, - -lat }{ }^{2} *\right)\end{array}$ & -99.57 & 7 & 1.11 & 0.13 \\
\hline
\end{tabular}




\begin{tabular}{|c|c|c|c|c|c|c|}
\hline & & $\begin{array}{l}\text { Model } 5 \text { (+supcan, +medlpin, - } \\
\left.\text { ecosite, -latcorr*, - -lat }{ }^{2} *\right)\end{array}$ & -99.81 & 7 & 1.60 & 0.11 \\
\hline \multirow[t]{3}{*}{ Pileated Woodpecker } & 154.84 & Model 1 (+supcan, -totalba, +ecosite) & -72.42 & 5 & 0.00 & 0.36 \\
\hline & & Model 2 (+supcan, -conba, -age) & -72.60 & 5 & 0.35 & 0.30 \\
\hline & & Model 3 (-conba, +deciba, -ecosite) & -73.21 & 5 & 1.58 & 0.16 \\
\hline Red-breasted Nuthatch & 187.35 & $\begin{array}{l}\text { Model } 1 \text { (+conba*, -totalba*, - } \\
\left.\text { ecosite*, -lgcorr*, -lat }^{2} *\right)\end{array}$ & -86.68 & 7 & 0.00 & 0.81 \\
\hline \multirow[t]{2}{*}{ Scarlet Tanager } & 112.59 & $\begin{array}{l}\text { Model } 1 \text { (-medlpin, -conba*, }+ \\
\text { totalba*, +ecosite*, -latcorr* }{ }^{*}+ \\
\left.\text { lglat }^{*},+\operatorname{lat}^{2},+\lg ^{2}\right)\end{array}$ & -46.30 & 10 & 0.00 & 0.50 \\
\hline & & $\begin{array}{l}\text { Model } 2(- \text { supcan },+ \text { totalba },+ \text { age } *,+ \\
\left.\text { ecosite*, -latcorr*, }+ \text { lglat, }+\operatorname{lat}^{2},+\lg ^{2} *\right)\end{array}$ & -46.97 & 10 & 1.35 & 0.25 \\
\hline \multirow[t]{5}{*}{ Swainson's Thrush } & 261.15 & $\begin{array}{l}\text { Model } 1 \text { (-supcan*, +conba, +totalba, + } \\
\left.\text { ecosite, -lgcorr*, -lg }{ }^{2} *\right)\end{array}$ & -122.58 & 8 & 0.00 & 0.35 \\
\hline & & $\begin{array}{l}\text { Model } 2(+ \text { conba, +deciba, +age, }- \\
\left.\text { ecosite, }+ \text { mps, -lgcorr*, - - } \lg ^{2 *}\right)\end{array}$ & -123.36 & 8 & 1.56 & 0.16 \\
\hline & & $\begin{array}{l}\text { Model } 3 \text { (-supcan, +totalba*,+ } \\
\left.\text { ecosite, }+ \text { mps,-lgcorr*, } \text {-lg }^{2} *\right)\end{array}$ & -123.38 & 8 & 1.60 & 0.16 \\
\hline & & $\begin{array}{l}\text { Model } 4 \text { (+supcan, +conba, +age, - } \\
\left.\text { mps, - -lgcorr*, } \lg ^{2} *\right)\end{array}$ & -124.44 & 7 & 1.73 & 0.15 \\
\hline & & $\begin{array}{l}\text { Model } 5 \text { (-supcan, -medlpin, + } \\
\text { totalba*, -age, -lgcorr*, -lg2*) }\end{array}$ & -123.57 & 8 & 1.99 & 0.13 \\
\hline \multirow[t]{2}{*}{ Winter Wren } & 224.56 & $\begin{array}{l}\text { Global (+supcan, -medlpin,+conba*, - } \\
\text { totalba, +age, }- \text {-ecosite*, -mps, + } \\
\left.\text { latcorr, +lglat, }+\operatorname{lat}^{2 *},+\lg ^{2}\right)\end{array}$ & -99.28 & 13 & 0.00 & 0.50 \\
\hline & & $\begin{array}{l}\text { Model } 1 \text { (-medlpin, +conba*, -totalba, - } \\
\left.\text { ecosite*, +latcorr, +lglat, }+\operatorname{lat}^{2},+\lg ^{2}\right)\end{array}$ & -102.40 & 10 & 0.23 & 0.45 \\
\hline $\begin{array}{l}\text { Total species richness } \\
\text { (plus raptors and corvids) }\end{array}$ & 277.78 & $\begin{array}{l}\text { Global }(+ \text { supcan*, +medlpin*, } \\
\text { conba*, +deciba*, -totalba, -age, - } \\
\text { ecosite },+ \text { mps })\end{array}$ & -128.89 & 10 & 0.00 & 0.89 \\
\hline \multirow[t]{3}{*}{$\begin{array}{l}\text { Total species abundance } \\
\text { (plus raptors and corvids) }\end{array}$} & 447.67 & $\begin{array}{l}\text { Model } 1 \text { (-medlpin, +deciba, +age, + } \\
\left.\text { mps*, +latcorr, - -lg } \mathbf{2}^{*}\right)\end{array}$ & -215.84 & 8 & 0.00 & 0.38 \\
\hline & & $\begin{array}{l}\text { Model } 2 \text { (+supcan, -medlpin, -totalba, - } \\
\left.\text { ecosite, +latcorr*, }-\lg ^{2} *\right)\end{array}$ & -216.23 & 8 & 0.79 & 0.26 \\
\hline & & $\begin{array}{l}\text { Global (+supcan, +medlpin, +conba, }+ \\
\text { deciba, -totalba, +age, -ecosite, }+ \text { mps, }+ \\
\left.\text { latcorr, - } \lg ^{2} *\right)\end{array}$ & -212.67 & 12 & 1.67 & 0.17 \\
\hline
\end{tabular}

Erratum: In the original publication the footnotes were incorrectly identified. The error was fixed on 15 May 2013.

${ }^{\dagger}$ Minimum AIC is the lowest AIC score. AIC $=(-2 * \log$-likelihood $)+(2 * \mathrm{~K})$.

${ }^{\ddagger}$ Model: These are the candidate models representing different combinations of tree density, Ontario Forest Resource Inventory (FRI), ecosite, and landscape variables (trend surface variables were included in all models but are not shown in the table).

$\S-2 \mathrm{LL}$ is $-2 * \log$-likelihood

${ }^{\prime} \mathrm{K}=$ the number of model parameters used to calculate AIC.

" $\triangle \mathrm{AIC}$ is a model's AIC minus the best model's AIC.

\# wi or Akaike weights are calculated as follows: $\mathrm{w}=\operatorname{EXP}\left(-0.5^{*} \Delta \mathrm{AIC}\right)$. This is the same as taking the inverse natural logarithm of $\left(-0.5^{*}\right.$ $\Delta \mathrm{AIC})$.

wi (Akaike weights) are the normalized relative model likelihoods and are calculated as follows:

wi $=\exp \left(-0.5^{*} \Delta \mathrm{AICi}\right) / \Sigma \mathrm{Rr}=1 \exp \left(-0.5^{*} \Delta \mathrm{r}\right)$, where $\mathrm{R}$ is the set of candidate models. Note that this first part of the expression matches what is described above. These normalized Akaike weights can be used to compare the relative importance of the models as discussed in the text.

pine. Density of medium/large pine trees was the most important variable for Brown Creeper, overall bird abundance, and species richness, and it was second-most important for Winter Wren (second equal with ecosite; Tables 2 and 3).

The $\triangle$ AIC values indicated that models containing supercanopy pine were top-ranked for three species:
Blackburnian Warbler, Black-throated Green Warbler, and Pileated Woodpecker (Table 2). And, supercanopy pine was included in the second-ranked models for eight species: Blackand-white Warbler, Blackburnian Warbler, Blue-headed Vireo, Evening Grosbeak Coccothraustes vespertinus, Least Flycatcher Empidonax minimus, Northern Parula, Pileated 
Table 3. Importance of different variables derived from AIC models for individual species, species richness, and overall abundance. Bolded values indicate species for which pine variables were most important. ${ }^{\text {a }}$

\begin{tabular}{|c|c|c|c|c|c|c|c|c|}
\hline Species/measure & $\begin{array}{c}\text { Supercanopy } \\
\text { pine }\end{array}$ & $\begin{array}{l}\text { Medium/large } \\
\text { pine }\end{array}$ & $\begin{array}{c}\text { Conifer } \\
\text { basal } \\
\text { area }\end{array}$ & $\begin{array}{l}\text { Deciduous } \\
\text { basal area }\end{array}$ & $\begin{array}{c}\text { Total } \\
\text { basal } \\
\text { area } \\
\end{array}$ & Ecosite & Age & $\begin{array}{c}\text { Mean } \\
\text { patch size }\end{array}$ \\
\hline Black-and-white Warbler & 0.48 & 0.15 & 0.91 & 0.94 & 0.09 & 0.61 & 0.91 & 0.36 \\
\hline Brown Creeper & 0.51 & 0.90 & 0.81 & & 0.41 & 0.50 & 0.81 & 0.80 \\
\hline Blue-headed Vireo & 0.72 & 0.53 & 0.50 & & 0.34 & 0.72 & 0.78 & 0.21 \\
\hline Blackburnian Warbler & 0.99 & 0.42 & 0.95 & 0.44 & 0.94 & 0.40 & 0.97 & 0.41 \\
\hline Black-throated Green Warbler & 0.75 & 0.21 & 0.85 & 0.52 & 0.91 & 0.75 & 0.56 & 0.10 \\
\hline Golden-crowned Kinglet & 0.37 & 0.26 & 0.93 & & 0.93 & 0.85 & 0.93 & 0.22 \\
\hline Least Flycatcher & 0.51 & 0.12 & & 1.00 & 0.69 & 0.67 & 0.87 & 0.20 \\
\hline Northern Parula Warbler & 0.65 & 0.19 & 0.75 & 0.59 & 0.45 & 0.40 & 0.54 & 0.15 \\
\hline Pine Warbler ${ }^{b}$ & 0.76 & 0.49 & & & 0.44 & 0.63 & 0.76 & 0.37 \\
\hline Pileated Woodpecker & 0.84 & 0.13 & 0.52 & 0.22 & 0.42 & 0.64 & 0.48 & 0.06 \\
\hline Red-breasted Nuthatch & 0.18 & 0.10 & 0.96 & & 0.91 & 1.00 & 0.10 & 0.06 \\
\hline Scarlet Tanager & 0.50 & 0.60 & 0.75 & 0.24 & 0.86 & 0.85 & 0.47 & 0.13 \\
\hline Swainson's Thrush & 0.84 & 0.18 & 0.71 & 0.21 & 0.34 & 0.72 & 0.49 & 0.21 \\
\hline Winter Wren & 0.53 & 0.95 & 1.00 & & 0.99 & 0.95 & 0.55 & 0.52 \\
\hline Total abundance & 0.55 & 0.81 & 0.26 & 0.64 & 0.43 & 0.45 & 0.72 & 0.55 \\
\hline Species richness & 0.97 & 0.99 & 0.90 & 0.92 & 0.96 & 0.97 & 0.92 & 0.91 \\
\hline
\end{tabular}

${ }^{\text {a }}$ See Table 1 for the variable units of measure.

${ }^{\mathbf{b}}$ Note that pine variables and Ontario Forest Resource Inventory (FRI) age were equally important for this species.

Woodpecker, and Pine Warbler. Models containing medium/ large pine were top-ranked for Blue-headed Vireo, Brown Creeper, Pine Warbler Scarlet Tanager, Winter Wren, and for total abundance and species richness; and, medium/large pine occurred in the second-ranked model for Blackburnian Warbler and Blue-headed Vireo, and for total abundance (Table 2).

Supercanopy pine and medium/large pine had a significant effect in the $p C C A$ ordination, even after controlling for basal area of nonpine conifer, basal area of deciduous trees, mean patch size, and the trend surface function $(\mathrm{F}=1.396, \mathrm{P}=$ 0.023). This demonstrated that large pine trees had a unique and significant effect on bird communities. Partitioned variance among the three main subsets (supercanopy and medium/large pine versus age, and basal area of nonpine conifer/deciduous versus landscape metrics) demonstrated that although the variation unique to supercanopy pine and medium/large pine was small, it was significant $(\mathrm{F}=1.356, \mathrm{P}$ =0.04; Fig. 5).

\section{Importance of patch size}

Patch size occurred in top-ranked models for eight species and was significant in two models, i.e., for Evening Grosbeak and for total abundance.
Fig. 5. Partitioned variance between supercanopy and medium/large pine (a); age, basal area of conifers, and basal area of deciduous trees (b); and landscape metrics (c). (d) = variance shared between (a) and (b); $g=$ variance shared between (a), (b), and (c). Residuals $=0.82$ is unexplained variance. Values show proportion of variance.

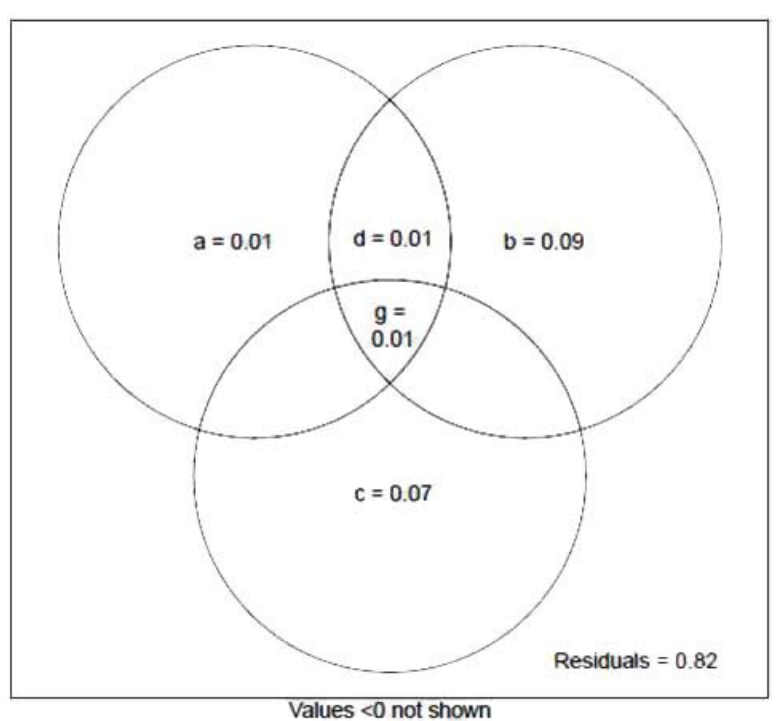


What thresholds of large pine density are required to predict the probability of bird species presence?

The ROC threshold graphs can be used to estimate the critical threshold for supercanopy pine, medium/large pine, or age. Our modeling predicted a threshold probability of occurrence for Brown Creeper at 0.33 with 62 stems $/ \mathrm{ha}\left(11.6 \mathrm{~m}^{2} / \mathrm{ha}\right)$ of medium/large pine trees (Fig. 6). For Pileated Woodpecker, the threshold probability of occurrence was 0.20 with 14 stems/ha (3.9 $\mathrm{m}^{2} / \mathrm{ha}$ ) of supercanopy pine trees (Fig. 7), and for Black-throated Green Warbler the threshold probability was 0.63 with 23 stems $/$ ha $\left(6.4 \mathrm{~m}^{2} / \mathrm{ha}\right)$ of supercanopy trees (Fig. 8). Finally, the computed threshold for the probability of occurrence of Blackburnian Warbler from the ROC curves was 0.81 at a stand age of 66 years (Fig. 9).

Fig. 6. Relationship between the density of medium/large pine trees and the probability of occurrence of Brown Creeper in pine forests. Threshold derived from ROC curve is shown as vertical line (see Methods).

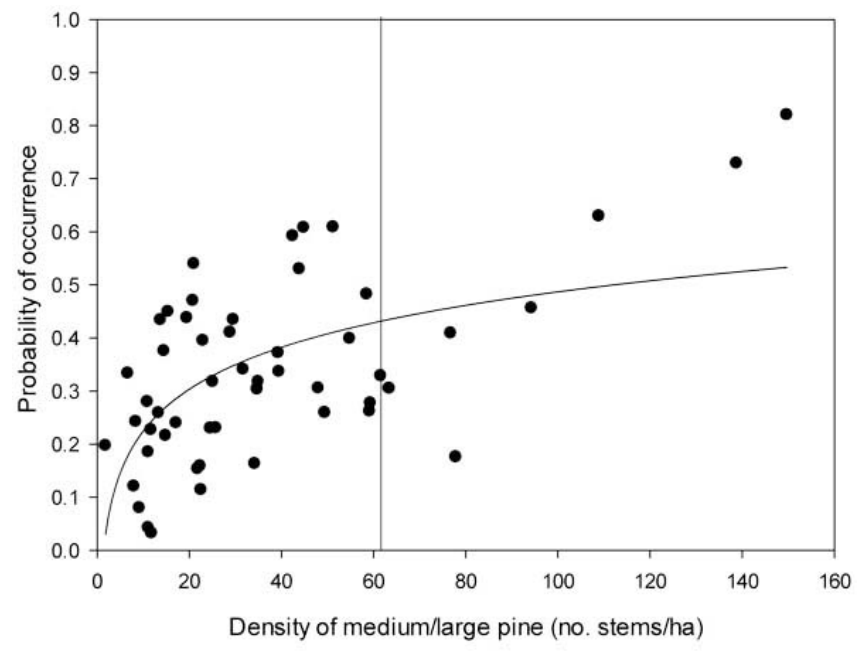

\section{DISCUSSION}

Species richness and overall abundance did not differ between old-growth stands and mature stands, which was inconsistent with our first prediction. However, Neotropical migrants were more abundant in old-growth stands than in mature forest stands, whereas the opposite was true for short-distance migrants. Of the 43 most common species, 15 had the highest mean counts in old-growth pine forests (three of which were significantly higher), while two species were significantly most abundant in mature stands.
Fig. 7. Relationship between the density of supercanopy pine trees and the probability of occurrence of Pileated Woodpecker in pine forests. Threshold derived from ROC curve is shown as vertical line (see Methods).

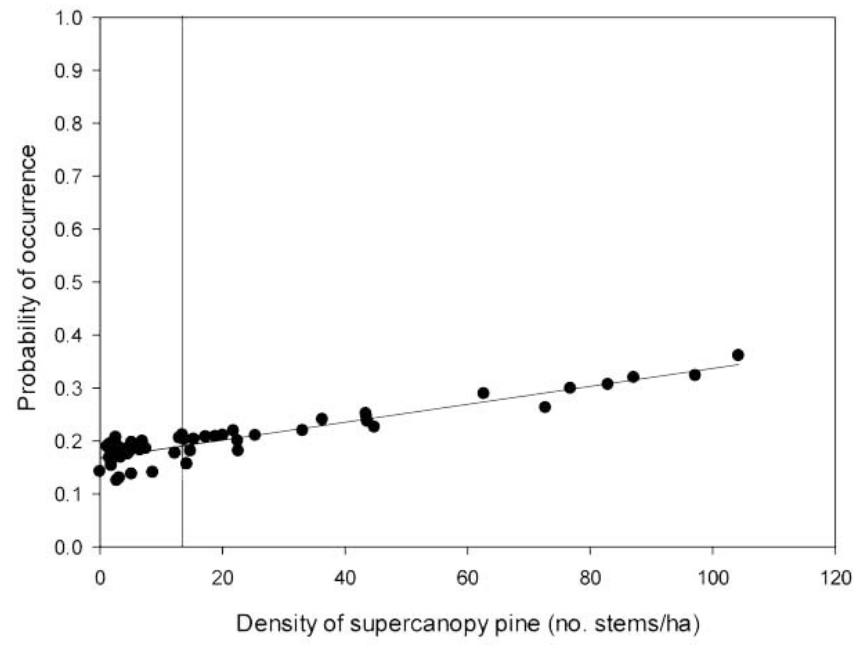

Fig. 8. Relationship between the density of supercanopy pine trees and the probability of occurrence of Blackthroated Green Warbler in pine forests. Threshold derived from ROC curve is shown as vertical line (see Methods).

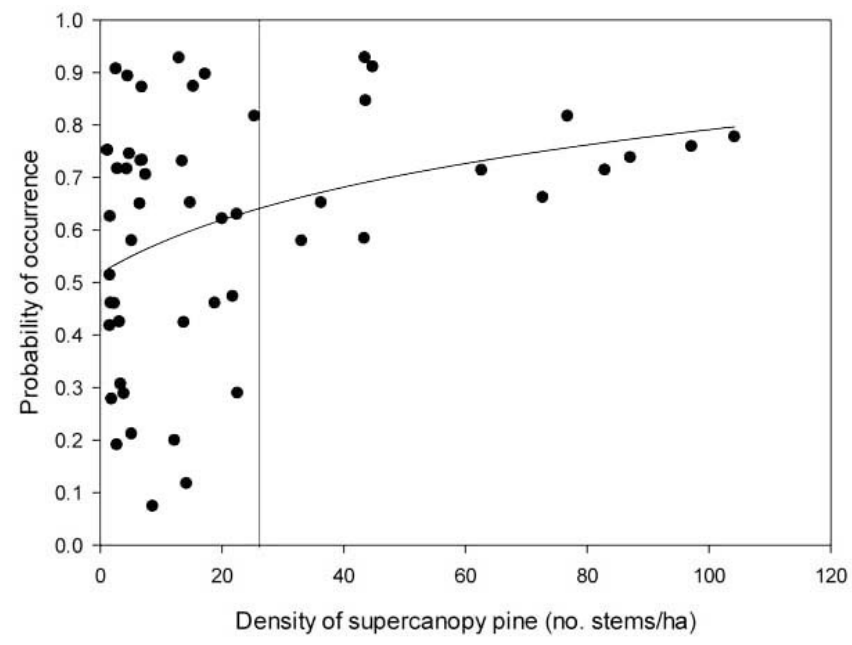


Fig. 9. Relationship between stand age and the probability of occurrence of Blackburnian Warbler in pine forests. Threshold derived from ROC curve is shown as vertical line (see Methods).



Single-species models demonstrated that density of supercanopy pine was a significant predictor for three species (two positive, one negative) and that medium/large pine was a significant predictor for two species and for overall species richness (all positive). Moreover, according to summed Akaike weights, density of supercanopy pine was the most important variable in models for four species, and it was second-most important for two other species and for overall species richness. Density of medium/large pine trees was the most important variable for one species, overall bird abundance, and species richness, and it was second-most important for one other species. These results supported our second hypothesis, i.e., that large pine trees would be an important habitat feature for some species. Although we found that bird assemblages in old-growth forests did not differ from those in mature stands, this could have been confounded by regional differences. Except for Algonquin and eastern Ontario, all pairwise comparisons between regions were significantly different, demonstrating the strong geographical variation among old pine bird assemblages. Finally, we found relatively weak support for landscape metrics playing an important role for bird species, although it was significant for Evening Grosbeak and total abundance; this may have been because even though old-growth stands were isolated, they still occurred within a continuously forested matrix. Our result for Evening Grosbeak is relevant given recent declines in the population indices of this species from the Breeding Bird Survey (Ontario Partners in Flight 2008).

\section{Which species are influenced by large pine trees, and why?}

Because of their low foliage volume and highly resinous and thick leaves (which contain secondary compounds rendering them unpalatable for most arthropods), pine forests usually support low bird densities (Hunter 1990). Few species prefer pine trees for foraging or shelter, except for Pine Warbler, which is a pine specialist (Rodewald et al. 1999), and both crossbill species that feed on pine seeds. Black-throated Green Warbler and Blackburnian Warbler are found in a range of mixedwood types, including those dominated by eastern hemlock Tsuga Canadensis (Morse and Poole 2005). Blackburnian Warbler uses white pine and red pine stands extensively, and its association with supercanopy pine trees in this study was therefore not surprising (see Morse 2004). The latter species appears to prefer old-growth forests or mature pine forests.

Aside from canopy-dwelling and foliage-gleaning warblers, our study also demonstrated that some snag, bark, or cavityusing species were more abundant in old-growth pine, or large pine was an important habitat component. Not surprisingly, this included Brown Creeper and Pileated Woodpecker, two species for which old-growth affinities in Canada have previously been suggested (Thompson et al. 1995a, Kirk and Naylor 1996, Flemming et al. 1999, Wintle et al. 2005, Poulin et al. 2008, 2010). However, Naylor et al. (1996) indicated that Pileated Woodpeckers use both mature and old-growth stands for nesting, but used old growth less.

Throughout its range, the Brown Creeper requires snags and broken stumps for nesting and large live trees for foraging. In New Hampshire, numbers of Brown Creepers were reduced in partial cuts (Costello et al. 2000, King et al. 2001). In the northern Appalachian Plateau in Pennsylvania, USA, Brown Creepers were more than twice as abundant in old-growth hemlock-hardwood than in younger forests (Haney and Schaadt 1996, Haney 1999). Moreover, numerous studies in the U.S. Pacific Northwest demonstrated that Brown Creepers are more abundant in old-growth stands or mature stands than in younger forests (reviewed by Hejl et al. 2002).

A positive association between counts for a bird species and density of supercanopy/large pine or higher counts in older pine forests does not necessarily indicate a dependency on oldgrowth pine. While Scarlet Tanagers prefer large trees in mature deciduous forests (Mowbray 1999), their higher abundance in old-growth pine stands was most likely related to the deciduous component or areal extent of stands. Although Swainson's Thrush was significantly more abundant in oldgrowth than in mature stands, stand structure is likely to be a more important predictor than supercanopy pine (i.e., dense shrub layer; Evans and Yong 2000). Indeed the coefficient with supercanopy trees was negative in the best model for this species. In the coniferous forests of the northern Rocky 
Mountains, Swainson's Thrush was more abundant in oldgrowth than in mature, rotation-age stands, and in unharvested areas than in recent clearcuts or where forest cover was substantially reduced (Hejl et al. 1995). However, in the northeastern United States no such differences have been recorded (see Evans and Yong 2000). Other species that were more abundant in stands containing old pine may also have responded to other structural features of these stands, such as shrubs. The Northern Parula was more abundant in old growth (and supercanopy pine was a significant predictor in the second-best model), but the model with a basal area of nonpine conifer was the top ranked, which is consistent with this species being associated with spruce/fir forests. Finally, a significant positive relationship between Black-throated Green Warbler abundance and supercanopy pine was found, which may be related to the structure of these old-growth stands and/or the presence of other conifers. However, in Maine and Massachusetts this species is common in white pine forests (Morse and Poole 2005).

Despite choosing all of our stands in continuously forested landscapes, there were substantial regional differences in bird communities across the $1200-\mathrm{km}$ wide study area. Whether these differences were due to regional differences in bird communities or biases in the range of habitats sampled in the five regions is not known. Nevertheless, a wide range of stand types were sampled in the northwest and Temagami regions that remained quite distinct, demonstrating that the bird communities differed. Moreover, spatial location explained more variation in the bird community than local tree supply. Interestingly, Thompson et al. (1995a) also found substantial regional differences in the communities of carabid beetles, ants, salamanders, resident birds, and small mammals; these differences were greatest between pine stands in the northwestern region and stands in the northeastern region and the Algonquin region.

\section{Conservation implications}

In Ontario, and in eastern North America more generally, most of the remaining old-growth red pine and white pine forests containing very large trees have been fragmented and isolated by a long history of timber harvesting (Aird 1985, Frelich and Reich 1996, Haney and Schaadt 1996). In our 300,000-km² study area in northwestern and eastern Ontario, red pine and white pine forests comprise only $2.3 \%$ of the land area (Perera and Baldwin 1993). The continued loss of supercanopy pine has resulted in many stands reverting to hardwoods (Aird 1985, Thompson et al. 2006). Coupled with this, the geographical range of white pine has retracted greatly over the last 6000 years (Pielou 1991), although northern remnants still remain.

Our results suggested that, at least in Ontario, abundance of several bird species was higher in old-growth pine than in mature pine, or that supercanopy pine was an important feature. These species included Black-throated Green Warbler and Blackburnian Warbler, both of which are listed as Continental and Regional Stewardship species (Northern Forest Avifaunal Biome) and are two of seven priority species of conservation concern in coniferous or mixed coniferous forests in Bird Conservation Region 12 (Ontario Partners in Flight 2008). Current forest management in pine stands may be effective in maintaining higher abundances of these species, as well as of Brown Creeper and Pileated Woodpecker. Therefore, they may be good indicators to guide management in old pine forests.

Our results could inform the number of medium/large or supercanopy pine trees needed to maintain avian species preferring old growth in shelterwood cuts. For example, regeneration cuts in shelterwood management for red pine and white pine in Ontario normally maintain a basal area of 12 to $16 \mathrm{~m}^{2} / \mathrm{ha}$ (about $100 \mathrm{stems} / \mathrm{ha}$, mostly medium and large-sized trees; B. J. Naylor, Ontario Ministry of Natural Resources, personal communication), and thus would be sufficient to meet the threshold of occurrence for Brown Creeper $\left(11.6 \mathrm{~m}^{2} /\right.$ ha). The latter basal area translates to a stem density of 59 trees of $50+\mathrm{cm} \mathrm{dbh} / \mathrm{ha}$, given that a single $50-\mathrm{cm}$ dbh tree has a basal area of $0.196 \mathrm{~m}^{2}$. However, the first removal (typically around 50 stems/ha; see Kingsley and Nol 1999) would not leave sufficient trees for the threshold probability of occurrence for Brown Creepers. The high threshold for this species should be treated with caution as the ROC was close to 0.7 , which is the limit for a useful model. The final removal leaves only about 25 stems/ha (10 cavity trees, 10 veterans, and 5 other stems), which again would be insufficient. Moreover, the number of supercanopy trees left may be below the threshold for occurrence for Pileated Woodpeckers or Black-throated Green Warblers based on our model. However, these predicted thresholds for managed stands should be tested by comparing shelterwood managed stands to mature stands and old-growth stands at each of the removal stages.

It is important to note that Black-throated Green Warblers occur in a wide variety of forest types but we do not have information on the contribution of different stand types to overall population viability. Although Brown Creepers are not dependent on old-growth pine-they also occur in old hardwood and mixedwood stands (Wintle et al. 2005; Poulin et al. 2008, 2010; Naylor et al. unpublished data)—retaining pine stands that have these "old-growth" characteristics on the landscape could help to maintain higher abundance of this species.

Over the past 20 years the emulation of natural disturbances (Bergeron and Harvey 1997, Pinto 1998, Perera et al. 2004, Ontario Ministry of Natural Resources 2010) has been adopted as the best means of sustainable forest management to conserve biodiversity. This shift in emphasis for forest management began in Ontario with the Crown Forest 
Sustainability Act (1994) that required forest management to emulate natural disturbance (Pinto 1998), with specific guidelines for emulating natural disturbances being adopted in Ontario (Ontario Ministry of Natural Resources 2010). There is direction in these guidelines for retention and management of old-growth characteristics that are an outcome of natural disturbance dynamics. A combination of retaining stands of old-growth pine by protection in parks, landscape management of forest age classes, and specific silvicultural practices to maintain species composition and structure could help maintain avian biodiversity in red pine and white pine forests in Ontario. Protected areas could serve as benchmarks to compare old-growth stands with managed stands, and to strive to maintain old-growth features in some managed stands (Haney 1996). However, protected areas of old-growth pine are likely too few, too small in area, and too fragmented and isolated to be maintained in the long term because they are vulnerable to stochastic environmental events such as fires and windthrow, and to natural succession to other forest types in some areas. Perera and Baldwin (1993) found that most stands are small ( $<100 \mathrm{ha}$ ), with few being $\geq 500$ ha. It is possible that the stands may be losing species over time because of their small size and/or isolation from other pine stands, as well as due to timber harvesting and other land uses in the surrounding landscape matrix.

Better understanding of stand and landscape composition in relation to population dynamics of the bird species that are more abundant in old growth is needed to predict long-term conservation needs (Thompson et al. 1995a). An immediate need is to compare managed pine stands to fire-origin mature stands and old-growth stands to evaluate expectations for bird communities and relative species abundances. Recent forest management guidelines (Ontario Ministry of Natural Resources 2010) require leaving structures for birds that use mature and older pine forests. The effectiveness of these guidelines with respect to emulation of natural disturbances has yet to be examined. Further, the influence of patch size and edge metrics in mature and old-growth pine needs further evaluation. At the stand level we recommend that some shelterwood or selection cuts maintain specific densities of medium/large pines (e.g., $>60$ stems/ha) or supercanopy pine trees (e.g., $>14$ or $>23$ stems/ha) within stands, in addition to current guidelines. Forest managers should also compare the probability of occurrence for Blackburnian Warblers, Blackthroated Green Warblers, Brown Creepers, and Pileated Woodpeckers in these managed stands to their occurrence in mature stands and old-growth stands in each geographic region.

${ }^{[1]} \mathrm{We}$ use the term "sustainable harvesting" to refer to ecologically sustainable forestry, and "selective logging or harvesting" to refer to forestry that is not sustainable. Historically, old-growth pine forests were logged/harvested whereas current shelterwood management of white pine would be referred to as sustainable harvesting.
Responses to this article can be read online at:

http://www.ace-eco.org/issues/responses.php/503

\section{Acknowledgments:}

This paper is dedicated to two people who passed away too young: Daniel Albert Welsh, cherished friend, colleague, and mentor, in January 2001; and Chris Michener, a dear friend and companion during four seasons of fieldwork with the first author, in June 2011. Dan Welsh was the originator of this study. Funding for fieldwork and preparation of this paper was provided by the Ontario Ministry of Natural Resources, while funding for data analysis was from the Canadian Wildlife Service (Ontario Region), Environment Canada; Domtar (TEMBEC); and the Ontario Ministry of Natural Resources. Bird surveys were done by volunteers for the Forest Bird Monitoring Program; bird and vegetation surveys were carried out under contract by P. Burke, M. de Almeida, A. Harris, G. Holland, M. Kubisz, C. Michener (deceased), M. Mather, S. Phippen, A. White (deceased), J. Woodcock, and the first author. The Ontario Region of the Canadian Wildlife Service (courtesy of D. McNicol) supplied the bird databases. We would also like to thank D. Fillman, R. Russell, and B. Campbell for their invaluable help. Landscape metrics were calculated by K. Kahtava and D. Ortiz of the Canadian Forest Service, Sault Ste. Marie. M. St. Eloi and M. Radford of the Ontario Forest Resource Inventory unit in Sault Ste. Marie supplied the FRI data, for which are most grateful. We thank C. Widdifield for preparing Figure 1, D. Bert for helping with finalizing figures, $L$. Olson for help with variance partitioning, and $R$. W. Brook for help with computing the ROC curves. $L$. Landriault, B. J. Naylor, R. W. Brook, K. Lindsay, two anonymous reviewers, T. Nudds, and M.-A. Villard also provided valuable comments on earlier drafts.

\section{LITERATURE CITED}

Adkisson, C. D. 1996. Red Crossbill (Loxia curvirostra). In A. Poole, editor. The birds of North America online. Cornell Lab of Ornithology, Ithaca, New York, USA. http://dx.doi. org/10.2173/bna.256

Aird, P. L. 1985. In praise of pine: the eastern white pine and red pine timber harvest from Ontario's Crown forest. Canadian Forest Service Report No. PI-X-52. Petawawa National Forestry Institute, Canadian Forest Service, Petawawa, Ontario, Canada.

Anderson, D. R., K. P. Burnham, and W. L. Thompson. 2000. Null hypothesis testing: problems, prevalence, and an alternative. Journal of Wildlife Management 64:912-923. http://dx.doi.org/10.2307/3803199

Baldwin, D. J., H. G. Godschalk, A. H. Perera, and B. P. Mooney. 1994. A GIS-based composite ranking system for eastern white pine and red pine forests in Ontario (GRASP). 
Forest Fragmentation and Biodiversity Project Report No. 15. Forest Landscape Ecology Program, Ontario Forest Research Institute, Ontario Ministry of Natural Resources, Ontario, Canada.

Barnes, B. V. 1989. Old-growth forests of the northern lake states: a landscape ecosystem perspective. Natural Areas Journal 9:45-57.

Batcheler, C. L. 1973. Estimating density and dispersion from truncated or unrestricted joint point-distance nearest neighbour distances. Proceedings of the New Zealand Ecological Society 20:131-147.

Batcheler, C. L. 1975. Probable limit of error of the point distance-neighbour distance estimate of density. Proceedings of the New Zealand Ecological Society 22:28-33.

Bebber, D. P., S. C. Thomas, W. G. Cole, and D. Balsillie. 2004. Diameter increment in mature eastern white pine Pinus strobus L. Trees 18:29-34.

Benkman, C. W. 1989. On the evolution and ecology of island populations of crossbills. Evolution 43:1324-1330. http://dx. doi.org/10.2307/2409369

Benkman, C. W. 1993. Logging, conifers and the conservation of crossbills. Conservation Biology 7:473-479. http://dx.doi. org/10.1046/j.1523-1739.1993.07030473.x

Bergeron, Y., and B. Harvey. 1997. Basing silviculture on natural ecosystem dynamics: an approach applied to the southern boreal mixedwood forest of Quebec. Forest Ecology and Management 92:235-242. http://dx.doi.org/10.1016/ S0378-1127(96)03924-2

Betts, M., and M.-A. Villard. 2009. Landscape thresholds in species occurrence as quantitative targets in forest management: generality in space and time? Pages 185-205 in M.-A. Villard and B.G. Jonsson, editors. Setting conservation targets for managed forest landscapes. Cambridge University Press, Cambridge, Cambridgeshire, UK.

Bibby, C. J., N. J. Burgess, and D. A. Hill. 2000. Bird census techniques. Second edition. British Trust for Ornithology and Royal Society for the Protection of Birds. Academic Press, San Diego, California, USA.

Bolgiano, C. 1989. A case for eastern old-growth. American Forests May/June 1989:26-50.

Borcard, D., P. Legendre, and P. Drapeau. 1992. Partialling out the spatial component of ecological variation. Ecology 73:1045-1055. http://dx.doi.org/10.2307/1940179

Bowman, J., G. J. Forbes, and T. G. Dilworth. 2001. The spatial component of variation in small mammal abundance measured at three scales. Canadian Journal of Zoology 79:137-144. http://dx.doi.org/10.1139/z00-188

Brotons, L., M. Mönkkönen, E. Huhta, A. Nikula, and A.
Rajasärkkä. 2003. Effects of landscape structure and forest reserve location on old-growth forest bird species in northern Finland. Landscape Ecology 18:377-393. http://dx.doi. org/10.1023/A:1026148825138

Burnham, K. P., and D. R. Anderson. 2002. Model selection and multimodel inference: a practical information-theoretic approach. Second edition. Springer-Verlag, New York,New York, USA.

Cadman, M. D., D. A. Sutherland, G. G. Beck, D. Lepage, and A. R. Couturier, editors. 2007. Atlas of the breeding birds of Ontario, 2001-2005. Bird Studies Canada, Environment Canada, Ontario Field Ornithologists, Ontario Ministry of Natural Resources, and Ontario Nature, Toronto, Canada.

Cameron, A. C., and P. K. Trivedi. 2001. Regression analysis of count data. Cambridge University Press, Cambridge, Cambridgeshire, UK.

Carleton, T. J. 2003. Old growth in the Great Lakes forest. Environmental Reviews 11:S115-S134. http://dx.doi.org/10.1139/ a03-009

Chambers, B. A., B. J. Naylor, J. Nieppola, B. Merchant, and P. Uhlig. 1997. Field guide to forest ecosystems of central Ontario. Field Guide FG-01. Ontario Ministry of Natural Resources, Ontario, Canada.

Clarke, K. R., and R. N. Gorley. 2006. Primer v6: usermanual/ tutorial. Primer-E Ltd., Lutton, Devon, UK.

Costello, C. A., M. Yamasaki, P. J. Pekins, W. B. Leak, and C. D. Neefus. 2000. Songbird response to group selection harvests and clearcuts in a New Hampshire northern hardwood forest. Forest Ecology and Management 127:41-54. http://dx. doi.org/10.1016/S0378-1127(99)00131-0

Crown Forest Sustainability Act, 1994. Statutes of Ontario. Canada.

Cushman, S. A., and K. McGarigal. 2002. Hierarchical, multiscale decomposition of species-environment relationships. Landscape Ecology 17:637-646. http://dx.doi.org/10.1023/ A:1021571603605

D'Agostino, R. B., A. Belanger, and R. B. D'Agostino, Jr. 1990. A suggestion for using powerful and informative tests of normality. The American Statistician 44:316-321. http://dx. doi.org/10.2307/2684359

Dawson, D. K., and M. G. Efford. 2009. Effect of distancerelated heterogeneity on population size estimates from point counts. Auk 126:100-111. http://dx.doi.org/10.1525/auk.2009.07197

DeGraaf, R. M., and D. D. Rudis. 1986. New England wildlife: habitat, natural history and distribution. USDA Forest Service General Technical Report NE-108. Northeastern Forest Experimental Station, Forest Service, U.S. Department of Agriculture, Broomall, Pennsylvania, USA. 
Dickerman, R.W. 1987. The "Old Northeasterner" subspecies of Red Crossbill. American Birds 41:189-194.

Dickson, J. G., F. R. Thompson, III, R. N. Conner, and K. Franzreb. 1995. Silviculture in central and southeastern oakpine forests. Pages 245-266 in T. E. Martin and D. M. Finch, editors. Ecology and management of Neotropical migratory birds: a synthesis and review of critical issues. Oxford University Press, New York, USA.

Drapeau, P., A. Leduc, J.-F Giroux, J.-P. Savard, Y. Bergeron, and W. L. Vickery. 2000. Landscape scale disturbances and changes in bird communities of boreal mixed-wood forests. Ecological Monographs 70:423-444. http://dx.doi. org/10.1890/0012-9615(2000)070[0423:LSDACI]2.0.CO;2

Elkie, P., M. Gluck, J. Boos, J. Bowman, C. Daniel, J. Elliott, D. Etheridge, D. Heaman, G. Hooper, R. Kushneriuk, G. Lucking, S. Mills, B. Naylor, F. Pinto, B. Pond, R. Rempel, K. Ride, A. Smiegielski, G. Watt, and M. Woods. 2009. Science and information in support of the forest management guide for landscapes: package " $A$ " simulations, rationale and inputs. Forest Policy Section, Ontario Ministry of Natural Resources, Toronto, Ontario, Canada.

Elkie, P. C., R. S. Rempel, and A. P. Carr. 1999. Patch analyst user's manual: a tool for quantifying landscape structure. Northwest Science and Technology Technical Manual TM-002. Centre for Northern Forest Ecosystem Research, Northwest Science and Technology, Ontario Ministry of Natural Resources, Thunder Bay, Ontario, Canada.

Environment Canada. 2006. Recovery strategy for the Red Crossbill, percna subspecies (Loxia curvirostra percna), in Canada [proposed]. Species at Risk Act Recovery Strategy Series. Environment Canada, Ottawa, Canada.

ESRI. 1999. ArcView software version 3.2. Redland, Ohio, USA.

Evans M. D., and W. Yong. 2000. Swainson's Thrush (Catharus ustulatus). In A. Poole, editor. The birds of North America online. Cornell Lab of Ornithology, Ithaca, New York, USA. http://dx.doi.org/10.1093/jts/50.2.845

FAO. 2010. Global forest resources assessment, main report. FAO Forestry Paper 163. Food and Agriculture Oranisation of the United Nations, Rome, Italy.

Farnsworth, G. L., K. H. Pollock, J. D. Nichols, T. R. Simmons, J. E. Hines, and J. R. Sauer. 2002. A removal model for estimating detection probabilities from point count surveys. Auk 119:414-425 http://dx.doi.org/10.1642/0004-8038(2002) 119[0414:ARMFED]2.0.CO;2

Flemming, S. P., G. L. Holloway, E. J. Watts, and P. S. Lawrence. 1999. Characteristics of foraging trees selected by Pileated Woodpeckers in New Brunswick. Journal of Wildlife Management 63:461-469. http://dx.doi.org/10.2307/3802631
Franklin, J. F. 1989. Structural and functional diversity in temperate forests. Pages 166-175 in E. O. Wilson, editor. Biodiversity. National Academy Press, Washington, D.C., USA.

Freemark, K. E., and D. A. Kirk. 2001. Birds on organic and conventional farms in Ontario: partitioning effects of habitat and practices on species composition and abundance. Biological Conservation 101:337-350. http://dx.doi.org/10.1016/ $\underline{\text { S0006-3207(01)00079-9 }}$

Frelich, L. E., and C. G. Lorimer. 1991. Natural disturbance regimes in hemlock-hardwood forests of the Upper Great Lakes region. Ecological Monographs 61:145-164. http://dx. doi.org/10.2307/1943005

Frelich, L. E., and P. B. Reich. 1996. Old growth in the Great Lakes Region. Pages 144-160 in M. B. Davis, editor. Eastern old growth forests. Island Press, Washington, D.C., USA.

Frotheringham, E. H. 1914. White pine under forest management. Bulletin of the U.S. Department of Agriculture, No. 13. Washington, D.C., USA.

Guyette, R. P., and D.C. Dey. 1995. Age, size and regeneration of old growth white pine at Dividing Lake Nature Reserve Algonquin Park, Ontario. Forest Research Report No. 131. Ontario Forest Research Institute, Sault Ste. Marie, Ontario, Canada.

Hagan, J. M., and S. L. Grove. 1999. Bird abundance and distribution in managed and old-growth forest in Maine. Report No. MM-9901. Manomet Center for Conservation Sciences, Brunswick, Maine, USA.

Haney, J. C. 1999. Hierarchical comparisons of breeding birds in old-growth conifer-hardwood forest on the Appalachian Plateau. Wilson Bulletin 111:89-99.

Haney, J. C., and C. P. Schaadt. 1996. Functional roles of eastern old growth in promoting forest bird diversity. Pages 76-88 in M. B. Davis, editor. Eastern old growth forests. Island Press, Washington, D.C., USA.

Hejl, S. J., R. L. Hutto, C. R. Preston, and D. M. Finch. 1995. The effects of silvicultural treatments in the Rocky Mountains. Pages 220-244 in T. E. Martin and D. M. Finch, editors. Ecology and management of Neotropical migratory birds: a synthesis and review of critical issues. Oxford University Press, New York, USA.

Hejl, S. J., K. R. Newton, M. E. McFadzen, J. S. Young, and C. K. Ghalambor. 2002. Brown Creeper (Certhia americana). The birds of North America online. Cornell Lab of Ornithology, Ithaca, New York, USA. http://dx.doi. org/10.2173/bna.669

Helle, P., and O. Jarvinen. 1986. Population trends of north Finnish land birds in relation to their habitat selection and 
changes in forest structure. Oikos 46:107-115. http://dx.doi. org $/ 10.2307 / 3565386$

Hunter, M. L., Jr. 1989. What constitutes an old-growth stand? Journal of Forestry 87(8):33-50.

Hunter, M. L. 1990. Wildlife, forests and forestry: principles of managing forests for biological diversity. Prentice Hall, Englewood Cliffs, New Jersey, U.S.A.

Jackson, J. A. 1994. Red-cockaded Woodpecker (Picoides borealis). The birds of North America online. Cornell Lab of Ornithology, Ithaca, New York, USA. http://dx.doi. org/10.2173/bna. 85

Jackson, J. A. 2002. Ivory-billed Woodpecker (Campephilus principalis). The birds of North America online. Cornell Lab of Ornithology, Ithaca, New York, USA. http://dx.doi. org/10.2173/bna.711

Johnson, D. H. 2008. In defense of indices: the case of bird surveys. Journal of Wildlife Management 72:857-868.

King, D. I., R. M. DeGraaf, and C. R. Griffin. 2001. Productivity of early successional shrubland birds in clearcuts and group cuts in an eastern deciduous forest. Journal of Wildlife Management 65:345-350. http://dx.doi.org/10.2307/3802914

Kingsley, A., and E. Nol. 1999. Bird responses to the first cut of the uniform shelterwood silvicultural system in white pine forest. Pages 89-102 in A. W. Diamond and D. N. Nettleship, editors. Biology and conservation offorest birds, proceedings of the Society of Canadian Ornithologists Special Science Symposium, Frederiction, New Brunswick, 23-25 August 1996. Society of Canadian Ornithologists Special Publication No. 1. Fredericton, New Brunswick, Canada.

Kirk, D. A., and K. A. Hobson. 2001. Bird-habitat relationships in jack pine boreal forests. Forest Ecology and Management 147:217-243. http://dx.doi.org/10.1016/S0378-1127 (00)00465-5

Kirk, D. A., and B. J. Naylor. 1996. Habitat requirements of the Pileated Woodpecker (Dryocopus pileatus) with special reference to Ontario. Technology Technical Report No. 46. South Central Science and Technology, Ontario Ministry of Natural Resources, Ontario, Canada.

Leadbitter, P., D. Euler, and B. Naylor. 2002. A comparison of historical and current forest cover in selected areas of the Great Lakes-St. Lawrence Forest of central Ontario. The Forestry Chronicle 78:522-529.

Legendre, P., 1993. Spatial autocorrelation: trouble or new paradigm? Ecology 74:1659-1673.

Legendre, P., and L. Legendre. 1998. Numerical ecology. Second English edition. Elsevier, Amsterdam, The Netherlands. http://dx.doi.org/10.1007/978-3-642-70880-0
Leverett, R. 1996. Definitions and history. Pages 76-88 in M. B. Davis, editor. Eastern old growth forests. Island Press, Washington, D.C., USA.

Linder, P., and L. Östlund. 1992. Changes in the boreal forest of Sweden 1870-1991. Svensk Botanisk Tidskrift. 86:199-215. http://dx.doi.org/10.1080/02827589809383006

Morse, D. A. 2004. Blackburnian Warbler (Setophaga fusca). The birds of North America online. Cornell Lab of Ornithology, Ithaca, New York, USA. [online] URL: http:// bna.birds.cornell.edu/bna/species/102.

Morse, D. H., and A. F. Poole. 2005. Black-throated Green Warbler (Setophaga virens).The birds of North America online. Cornell Lab of Ornithology, Ithaca, New York, USA. [online] URL: http://bna.birds.cornell.edu/bna/species/055.

Mosseler, A., I. Thompson, and B. A. Pendrel. 2003. Overview of old-growth forests in Canada from a science perspective. Environmental Reviews 11:S1-S7. http://dx.doi.org/10.1139/ a03-018

Mowbray, T. 1999. Scarlet Tanager (Piranga olivacea). The birds of North America online. Cornell Lab of Ornithology, Ithaca, New York, USA. [online] URL: http://bna.birds. cornell.edu/bna/species/479. http://dx.doi.org/10.2173/bna.479

Naylor, B. J. 1994. Managing wildlife habitat in red pine and white pine in Ontario. Forestry Chronicle 70:411-419.

Naylor, B. J., J. A. Baker, D. M. Hogg, J. G. McNicol, and W. R. Watt. 1996. Forest management guidelines for the provision of Pileated Woodpecker habitat. Forest Management Branch, Ontario Ministry of Natural Resources, Sault Ste. Marie, Ontario, Canada.

Nichols, J. D., J. E. Hines, J. R. Sauer, F. W. Fallon, F. E. Fallon, and P. J. Heglund. 2000. A double-observer approach for estimating detection probability and abundance from point counts. Auk 117:393-408. http://dx.doi.org/10.1642/0004-8038 (2000)117[0393:ADOAFE]2.0.CO;2

Ontario Ministry of Natural Resources. 2010. Forest Management Guide for Great Lakes-St. Lawrence forest landscapes (landscape guide). Toronto, Ontario, Canada.

Ontario Partners in Flight. 2008. Ontario landbird conservation plan: bboreal hardwood transition, North American Bird Conservation Region 12. Ontario Ministry of Natural Resources; Bird Studies Canada; and Environment Canada; Ontario, Canada.

Perera, A. H., and D. J. B. Baldwin. 1993. Spatial characteristics of eastern white pine and red pine forests in Ontario. Forest Fragmentation and Biodiversity Project Report No. 9. Ontario Forest Research Institute, Ontario Ministry of Natural Resources, Sault Ste. Marie, Ontario, Canada. 
Perera, A. H., L. J. Buse, and M. Weber, editors. 2004. Emulating natural forest landscape disturbances. Columbia University Press, New York, USA.

Peres-Neto, P. R., Legendre, P., Dray, S., and Borcard, D. 2006. Variance partitioning of species data matrices: estimation and comparison of fractions. Ecology 87:2614-2625.http://dx.doi.org/10.1890/0012-9658(2006)87 [2614:VPOSDM]2.0.CO;2

Pileou, E. C. 1991. After the ice age: the return of life to glaciated North America. University of Chicago Press, Chicago, Illinois, USA.

Pinto, F., S. Romaniuk, and M. Ferguson. 2008. Changes to preindustrial forest tree composition in central and northeastern Ontario, Canada. Canadian Journal of Forest Research 38:1842-1854. http://dx.doi.org/10.1139/X08-034

Pinto, F. N. L., writing team coordinator. 1998. A silvicultural guide for the Great Lakes-St. Lawrence conifer forest in Ontario. Ontario Ministry of Natural Resources, Toronto, Canada.

Plonski, W. L. 1981. Normal yield tables (metric) for major forest species of Ontario. Division of Forestry, Ontario Ministry of Natural Resources, Toronto, Ontario, Canada.

Poulin, J.-F., M.-A. Villard, M. Edman, P. J. Goulet, and A.M. Eriksson, 2008. Thresholds in nesting habitat requirements of an old forest specialist, the Brown Creeper (Certhia americana), as conservation targets. Biological Conservation 141:1129-1137. http://dx.doi.org/10.1016/j.biocon.2008.02.012

Poulin, J-F., M-A. Villard, and S. Haché. 2010. Short-term demographic response of an old forest specialist to experimental selection harvesting. ÉcoScience 17:20-27. http://dx.doi.org/10.2980/17-1-3297

Rajora, O. P., L. DeVerno, A. Mosseler, and D. J. Innes. 1998. Genetic diversity and population structure of disjunct Newfoundland and central Ontario populations of eastern white pine. Canadian Journal of Botany 76:500-508.

Ralph, C. J., J. R. Sauer, and S. Droege, technical editors. 1995. Monitoring bird populations by point counts. General Technical Report PSW-GTR-149. Pacific Southwest Research Station, Forest Service, USDA Forest Service, Albany California, USA.

R Development Core Team. 2007. R: a language and environment for statistical computing. R Foundation for Statistical Computing, Vienna, Austria.

Rich, T. D., C. J. Beardmore, H. Berlanga, P. J. Blancher, M. S. W. Bradstreet, G. S. Butcher, D. W. Demarest, E. H. Dunn, W. C. Hunter, E. E. Inigo-Elias, J. A. Kennedy, A. M. Martell, A. O. Panjabi, D. N. Pashley, K. V. Rosenberg, C. M. Rustay, J. S. Wendt, and T. C. Will. 2004. Partners in Flight North American Landbird Conservation Plan. Cornell Lab of Ornithology, Ithaca, New York, USA.
Rodewald, P. G., J. H. Withgott, and K. G. Smith. 1999. Pine Warbler (Setophaga pinus). The birds of North America online. Cornell Lab of Ornithology, Ithaca, New York, USA. [online] URL: http://bna.birds.cornell.edu/bna/species/438.

Ruggiero, L. F., K. B. Aubry, A. B. Carey, and M. H. Huff, editors. 1991. Wildlife and vegetation of unmanaged Douglas fir forests. General Technical Report PNW-GTR-285. Pacific Northwest Research Station, Forest Service, USDA, Portland, Oregon, USA.

SAS Institute. 2008. SAS/STAT user's guide: statistics, release 8. Cary, North Carolina, USA.

Secretariat of the Convention on Biological Diversity. 2010. Global biodiversity outlook 3. Montreal, Quebec, Canada.

StataCorp. 2003. Stata statistical software: release 8.0. College Station, Texas, USA.

Suffling, R., M. Evans, and A. Perera. 2003. Presettlement forest in southern Ontario: ecosystems measured through a cultural prism. Forestry Chronicle 79:485-501.

ter Braak, C. J. F. 1995. Ordination. Pages 91-173 in R. H. G. Jongman, C. J. F. ter Braak and O. F. R. van Tongeren, editors. Data analysis in community and landscape ecology. Cambridge University Press, Cambridge, Cambridgeshire, UK. http://dx.doi.org/10.4324/9780203180419.ch5

ter Braak, C. J. F., and P. Smilauer. 2002. CANOCO reference manual and CanoDraw for Windows user's guide: software for community ordination (version 4.5). Microcomputer Power, Ithaca, New York, USA.

Thomas, J. W., L. F. Ruggiero, R. W. Mannan, J. W. Schoen, and R. A. Lancia. 1988. Management and conservation of oldgrowth forests in the United States. Wildlife Society Bulletin 16:252-262.

Thompson, F. R. III, J. R. Probst, and M. G. Raphael. 1995b. Impacts of silviculture: overview and management recommendations. Pages 201-219 in T. E. Martin and D. M. Finch, editors. Ecology and management of Neotropical migratory birds: a synthesis and review of critical issues. Oxford University Press, New York, New York, USA.

Thompson, I. D. 2000. Forest vertebrates of Ontario: patterns of distribution. Pages 54-73 in A. H. Perera, D. L. Euler, and I. D. Thompson, editors. Ecology of a managed terrestrial landscape: Patterns and processes of forest landscapes in Ontario. University of British Columbia Press, Vancouver, British Columbia, Canada.

Thompson, I. D., A. Applejohn, T. S. Jung, and L. A. Walton. 1995a. A short-term study of the faunal associations in old white pine ecosystems. Forest Fragmentation and Biodiversity Project Report No. 21. Ontario Forest Research Institute, Ontario Ministry of Natural Resources, Sault Ste. Marie, Ontario, Canada. 
Thompson, I. D., J. A. Baker, S. J. Harmon, R. S. Rempel, and K. J. Szuba. 2009. Forest birds and forest management in Ontario: status, management and policy. Forestry Chronicle 85:245-257.

Thompson, I. D., S. C. Maher, D. P. Rouillard, J. M. Fryxell, and J. A. Baker. 2007. Accuracy of forest inventory mapping: some implications for boreal forest management. Forest Ecology and Management 252:208-221. http://dx.doi. org/10.1016/j.foreco.2007.06.033

Thompson, I. D., J. H. Simard, and R. D. Titman. 2006. Historical changes in white pine (Pinus strobus L.) density in Algonquin Park, Ontario, during the $19^{\text {th }}$ century. Natural Areas Journal 26:61-71. http://dx.doi.org/10.3375/0885-8608 (2006)26[61:HCIWPP]2.0.CO;2

Uhlig, P., A. Harris, G. Craig, C. Bowling, B. Chambers, B. Naylor, and G. Beemer. 2001. Old growth definition for Ontario. Ontario Ministry of Natural Resources, Toronto, Canada.

Virkkala, R. 1989. Short-term fluctuations of bird communities and populations in virgin and managed forest in Northern Finland. Annales Zoologica Fennici 26:277-285.

Welsh, D. A. 1995. An overview of the Forest Bird Monitoring Program in Ontario, Canada. Pages 93-97 in C. J. Ralph, J. R. Sauer, and S. Droege, editors. Monitoring bird populations by point counts. Pacific Southwest Research Station, General Technical Report PSW-GTR-149. Forest Service, USDA, Albany, California, USDA.

Welsh, D. A., T. Clark, and K. Clark. 1992. Fauna of red and white pine old-growth forests in Ontario: Issues and recommendations for research. Forest Fragmentation and Biodiversity Project Report No. 3. Ontario Forest Research Institute, Ontario Ministry of Natural Resources. Sault Ste Marie, Ontario, Canada.

Whitney, G. G. 1986. Relation of Michigan's presettlement pine forests to substrate and disturbance history. Ecology 67:1548-1559. http://dx.doi.org/10.2307/1939085

Wintle, B. A., S. A. Bekessy, L. A. Venier, J. L. Pearce, and R. A. Chisholm. 2005. Utility of dynamic-landscape metapopulation models for sustainable forest management. Conservation Biology 19:1930-1943. http://dx.doi.org/10.1111/ j.1523-1739.2005.00276.x

Wong, I. W., D. K. McNicol, P. Fong, D. Fillman, J. Neysmith, and R. Russell. 2003. The Wildspace ${ }^{\mathrm{TM}}$ decision support system. Environmental Modelling \& Software 18 (2003):521-530.

Wray, D. 1986. Managing white pine in Ontario. Pp. 67-69 in D. T. Funk, editor, Eastern white pine: today and tomorrow, symposium proceedings, 12-14 June, 1985, Durham, NH. General Technical Report WO-51. Northeastern Forest
Experiment Station, Forest Service, USDA, Durham, New Hampshire, USA. 
Appendix 1. Candidate models for 15 species in old growth and younger pine forest stands. See Table 1 for predictor variable acronyms.

$\mathrm{K}$ is the number of model parameters (number of variables +2 ) used in calculation of AIC. Note that $\mathrm{K}$ may change for global model if a variable drops out. TSF is the trend surface function used in the models.

Black-and-white Warbler (BAWW)

A priori selected variables are in bold text.

\begin{tabular}{|c|c|c|c|c|c|c|c|}
\hline & & global & \multicolumn{5}{|c|}{ Tree density+FRI+ecosite+landscape } \\
\hline Subset & Var & & & & & & \\
\hline Treeden & supcan & $\mathrm{x}$ & & $\mathrm{x}$ & $\mathrm{x}$ & & $\mathrm{x}$ \\
\hline & medlpin & $\mathrm{x}$ & & & $\mathrm{x}$ & $\mathrm{x}$ & \\
\hline & conba & $\mathrm{x}$ & $\mathrm{x}$ & $\mathrm{x}$ & & $\mathrm{x}$ & $\mathrm{x}$ \\
\hline & deciba & $\mathrm{x}$ & $\mathrm{x}$ & & $\mathrm{x}$ & & $\mathrm{x}$ \\
\hline & totalba & $\mathrm{x}$ & & $\mathrm{x}$ & & $\mathrm{x}$ & \\
\hline FRI & fixage & $\mathrm{x}$ & $\mathrm{x}$ & $\mathrm{x}$ & & $\mathrm{x}$ & $\mathrm{x}$ \\
\hline Ecosite & ecosite & $\mathrm{x}$ & $\mathrm{x}$ & & $\mathrm{x}$ & & \\
\hline Landscape & mps & $\mathrm{x}$ & & & & & $\mathrm{x}$ \\
\hline Spatial & trend surface & $\mathrm{x}$ & $\mathrm{x}$ & $\mathrm{X}$ & $\mathrm{X}$ & $\mathrm{x}$ & $\mathrm{X}$ \\
\hline & & Global & $\begin{array}{c}\text { TR } \\
\text { FRI }\end{array}$ & $\begin{array}{l}\text { TR- } \\
\text { FRI2 }\end{array}$ & $\begin{array}{l}\text { TR- } \\
\text { FRI3 }\end{array}$ & $\begin{array}{l}\text { TR- } \\
\text { FRI4 }\end{array}$ & TR-FRI5 \\
\hline
\end{tabular}

$\begin{array}{rrrrrrr}\mathrm{K} & 11 & 7 & 7 & 7 & 7 & 8 \\ \mathrm{TSF} & \text { lat2 } & & & & & \end{array}$

Blue-headed Vireo (BHVI)

A priori selected variables are in bold text.

\begin{tabular}{|c|c|c|c|c|c|c|c|}
\hline & & global & \multicolumn{5}{|c|}{ Tree density+FRI+ecosite+landscape } \\
\hline Subset & Var & & & & & & \\
\hline \multirow[t]{5}{*}{ Treeden } & supcan & $\mathrm{x}$ & $\mathrm{x}$ & $\mathrm{X}$ & $\mathrm{x}$ & & $\mathrm{x}$ \\
\hline & medlpin & $\mathrm{x}$ & & $\mathrm{x}$ & & $\mathrm{x}$ & \\
\hline & conba & $\mathrm{x}$ & $\mathrm{x}$ & & $\mathrm{x}$ & & $\mathrm{x}$ \\
\hline & deciba & & & & & & \\
\hline & totalba & $\mathrm{x}$ & & $\mathrm{x}$ & $\mathrm{x}$ & & \\
\hline FRI & fixage & $\mathrm{x}$ & $\mathrm{x}$ & & $\mathrm{x}$ & $\mathrm{x}$ & $\mathrm{x}$ \\
\hline Ecosite & ecosite & $\mathrm{x}$ & $\mathrm{x}$ & $\mathrm{x}$ & & $\mathrm{x}$ & \\
\hline Landscape & mps & $\mathrm{x}$ & & & & & $\mathrm{x}$ \\
\hline Spatial & trend surface & $\mathrm{x}$ & $\mathrm{x}$ & $\mathrm{x}$ & $\mathrm{x}$ & $\mathrm{x}$ & $\mathrm{X}$ \\
\hline & & Global & $\begin{array}{l}\text { TR- } \\
\text { FRI }\end{array}$ & $\begin{array}{l}\text { TR- } \\
\text { FRI2 }\end{array}$ & $\begin{array}{l}\text { TR- } \\
\text { FRI3 }\end{array}$ & $\begin{array}{l}\text { TR- } \\
\text { FRI4 }\end{array}$ & TR-F \\
\hline
\end{tabular}




$\begin{array}{rcccccc}\mathrm{K} & 11 & 8 & 8 & 8 & 7 & 8 \\ \text { TSF } & \text { latcorr lgcorr } & & & & & \end{array}$

Blackburnian Warbler (BLBW)

A priori selected variables are in bold text.

\begin{tabular}{|c|c|c|c|c|c|c|c|}
\hline & & global & \multicolumn{5}{|c|}{ Tree density+FRI+ecosite+landscape } \\
\hline Subset & Var & & & & & & \\
\hline \multirow[t]{5}{*}{ Treeden } & supcan & $\mathrm{x}$ & $\mathrm{x}$ & $\mathrm{x}$ & $\mathrm{x}$ & & $\mathrm{x}$ \\
\hline & medlpin & $\mathrm{x}$ & & $\mathrm{x}$ & & $\mathrm{x}$ & \\
\hline & conba & $\mathrm{x}$ & $\mathrm{x}$ & & $\mathrm{x}$ & $\mathrm{x}$ & \\
\hline & deciba & $\mathrm{x}$ & & $\mathrm{x}$ & & & $\mathrm{x}$ \\
\hline & totalba & $\mathrm{x}$ & $\mathrm{x}$ & & & & \\
\hline FRI & fixage & $\mathrm{x}$ & $\mathrm{x}$ & $\mathrm{x}$ & & $\mathrm{x}$ & \\
\hline Ecosite & ecosite & $\mathrm{x}$ & & & $\mathrm{x}$ & $\mathrm{x}$ & \\
\hline Landscape & mps & $\mathrm{x}$ & & & & & $\mathrm{x}$ \\
\hline \multirow[t]{3}{*}{ Spatial } & trend surface & $\mathrm{x}$ & $\mathrm{x}$ & $\mathrm{x}$ & $\mathrm{x}$ & $\mathrm{x}$ & $\mathrm{x}$ \\
\hline & & Global & $\begin{array}{l}\text { TR- } \\
\text { FRI1 }\end{array}$ & $\begin{array}{l}\text { TR- } \\
\text { FRI2 }\end{array}$ & $\begin{array}{c}\text { TR- } \\
\text { FRI3 }\end{array}$ & $\begin{array}{l}\text { TR- } \\
\text { FRI4 }\end{array}$ & TR-FRI5 \\
\hline & $\begin{array}{r}\mathrm{K} \\
\mathrm{TSF}\end{array}$ & $\begin{array}{c}11 \\
\text { lgcorr, } \lg 2\end{array}$ & 7 & 7 & 6 & 7 & 6 \\
\hline
\end{tabular}

Brown Creeper (BRCR)

A priori selected variables are in bold text.

\begin{tabular}{|c|c|c|c|c|c|c|c|}
\hline & & global & \multicolumn{5}{|c|}{ Tree density+FRI+ecosite+landscape } \\
\hline Subset & Var & & & & & & \\
\hline \multirow[t]{5}{*}{ Treeden } & supcan & $\mathrm{x}$ & $\mathrm{x}$ & $\mathrm{x}$ & $\mathrm{x}$ & & \\
\hline & medlpin & $\mathrm{x}$ & & $\mathrm{x}$ & & & $\mathrm{x}$ \\
\hline & conba & $\mathrm{x}$ & $\mathrm{x}$ & & & $\mathrm{x}$ & $\mathrm{x}$ \\
\hline & deciba & & & & & & \\
\hline & totalba & $\mathrm{x}$ & $\mathrm{x}$ & & $\mathrm{x}$ & $\mathrm{x}$ & \\
\hline FRI & fixage & $\mathrm{x}$ & $\mathrm{x}$ & & $\mathrm{x}$ & & $\mathrm{x}$ \\
\hline Ecosite & ecosite & $\mathrm{x}$ & & $\mathrm{x}$ & & $\mathrm{x}$ & \\
\hline Landscape & mps & $\mathrm{x}$ & & & & $\mathrm{x}$ & $\mathrm{x}$ \\
\hline \multirow[t]{3}{*}{ Spatial } & trend surface & $\mathrm{x}$ & $\mathrm{x}$ & $\mathrm{x}$ & $\mathrm{x}$ & $\mathrm{x}$ & $\mathrm{x}$ \\
\hline & & Global & $\begin{array}{l}\text { TR- } \\
\text { FRI1 }\end{array}$ & $\begin{array}{l}\text { TR- } \\
\text { FRI2 }\end{array}$ & $\begin{array}{l}\text { TR- } \\
\text { FRI3 }\end{array}$ & $\begin{array}{l}\text { TR- } \\
\text { FRI4 }\end{array}$ & TR-FRI5 \\
\hline & $\begin{array}{r}\mathrm{K} \\
\mathrm{TSF}\end{array}$ & 10 & 7 & 6 & 6 & 7 & 7 \\
\hline
\end{tabular}


Black-throated Green Warbler (BTNW)

A priori selected variables are in bold text.

\begin{tabular}{|c|c|c|c|c|c|c|c|}
\hline & & global & \multicolumn{5}{|c|}{ Tree density+FRI+ecosite+landscape } \\
\hline Subset & Var & & & & & & \\
\hline \multirow[t]{5}{*}{ Treeden } & supcan & $\mathrm{x}$ & $\mathrm{x}$ & $\mathrm{x}$ & & $\mathrm{x}$ & $\mathrm{x}$ \\
\hline & medlpin & $\mathrm{x}$ & & & & $\mathrm{x}$ & \\
\hline & conba & $\mathrm{x}$ & $\mathrm{x}$ & $\mathrm{x}$ & $\mathrm{x}$ & & $\mathrm{x}$ \\
\hline & deciba & $\mathrm{x}$ & $\mathrm{x}$ & & $\mathrm{x}$ & $\mathrm{x}$ & \\
\hline & totalba & $\mathrm{x}$ & & $\mathrm{x}$ & & & \\
\hline FRI & fixage & $\mathrm{x}$ & $\mathrm{x}$ & & $\mathrm{x}$ & $\mathrm{x}$ & $\mathrm{X}$ \\
\hline Ecosite & ecosite & $\mathrm{x}$ & & $\mathrm{x}$ & $\mathrm{x}$ & & \\
\hline Landscape & mps & $\mathrm{x}$ & & & & & $\mathrm{X}$ \\
\hline Spatial & trend surface & $\mathrm{x}$ & $\mathrm{x}$ & $\mathrm{x}$ & $\mathrm{x}$ & $\mathrm{x}$ & $\mathrm{X}$ \\
\hline & & Global & $\begin{array}{l}\text { TR- } \\
\text { FRI1 }\end{array}$ & $\begin{array}{l}\text { TR- } \\
\text { FRI2 }\end{array}$ & $\begin{array}{l}\text { TR- } \\
\text { FRI3 }\end{array}$ & $\begin{array}{l}\text { TR- } \\
\text { FRI4 }\end{array}$ & TR-FRI5 \\
\hline & $\begin{array}{r}\mathrm{K} \\
\mathrm{TSF}\end{array}$ & $\begin{array}{l}12 \\
\lg 2, \operatorname{lgcorr}\end{array}$ & 8 & 8 & 8 & 8 & 8 \\
\hline
\end{tabular}

Evening Grosbeak (EVGR)

A priori selected variables are in bold text.

\begin{tabular}{|c|c|c|c|c|c|c|c|}
\hline & & global & \multicolumn{5}{|c|}{ Tree density+FRI+ecosite+landscape } \\
\hline Subset & Var & & & & & & \\
\hline \multirow[t]{5}{*}{ Treeden } & supcan & $\mathrm{x}$ & & $\mathrm{x}$ & $\mathrm{x}$ & $\mathrm{x}$ & \\
\hline & medlpin & $\mathrm{x}$ & & & & $\mathrm{x}$ & \\
\hline & conba & $\mathrm{x}$ & $\mathrm{x}$ & $\mathrm{x}$ & & $\mathrm{x}$ & $\mathrm{x}$ \\
\hline & deciba & $\mathrm{x}$ & $\mathrm{x}$ & & $\mathrm{x}$ & & $\mathrm{x}$ \\
\hline & totalba & $\mathrm{x}$ & & & $\mathrm{x}$ & & \\
\hline FRI & fixage & $\mathrm{x}$ & $\mathrm{x}$ & & & $\mathrm{x}$ & $\mathrm{x}$ \\
\hline Ecosite & ecosite & $\mathrm{x}$ & & $\mathrm{x}$ & $\mathrm{x}$ & & $\mathrm{x}$ \\
\hline Landscape & mps & $\mathrm{x}$ & & & & & $\mathrm{x}$ \\
\hline \multirow[t]{3}{*}{ Spatial } & trend surface & $\mathrm{x}$ & $\mathrm{x}$ & $\mathrm{x}$ & $\mathrm{x}$ & $\mathrm{x}$ & $\mathrm{x}$ \\
\hline & & Global & $\begin{array}{l}\text { TR- } \\
\text { FRI1 }\end{array}$ & $\begin{array}{l}\text { TR- } \\
\text { FRI2 }\end{array}$ & $\begin{array}{c}\text { TR- } \\
\text { FRI3 }\end{array}$ & $\begin{array}{c}\text { TR- } \\
\text { FRI4 }\end{array}$ & TR-FRIS \\
\hline & $\begin{array}{r}\mathrm{K} \\
\mathrm{TSF}\end{array}$ & glat 11 & 6 & 6 & 7 & 7 & 8 \\
\hline
\end{tabular}

Golden-crowned Kinglet (GCKI)

A priori selected variables are in bold text.

\begin{tabular}{|l|l|c|c|c|c|c|c|}
\hline & & global & \multicolumn{4}{|c|}{ Tree density+FRI+ecosite+landscape } \\
\hline Subset & Var & & & & & & \\
\hline Treeden & supcan & $\mathrm{x}$ & $\mathrm{x}$ & $\mathrm{x}$ & & $\mathrm{x}$ & \\
\hline & medlpin & $\mathrm{x}$ & & $\mathrm{x}$ & & & $\mathrm{x}$ \\
\hline
\end{tabular}




\begin{tabular}{|c|c|c|c|c|c|c|c|}
\hline & conba & $\mathrm{x}$ & $\mathrm{x}$ & & $\mathrm{x}$ & & $\mathrm{x}$ \\
\hline & deciba & & & & & & \\
\hline & totalba & $\mathrm{x}$ & $\mathrm{x}$ & & $\mathrm{x}$ & $\mathrm{x}$ & \\
\hline FRI & fixage & $\mathrm{x}$ & $\mathrm{x}$ & & $\mathrm{x}$ & & $\mathrm{X}$ \\
\hline Ecosite & ecosite & $\mathrm{x}$ & & $\mathrm{x}$ & $\mathrm{x}$ & $\mathrm{x}$ & \\
\hline Landscape & mps & $\mathrm{x}$ & & & & & $\mathrm{x}$ \\
\hline Spatial & trend surface & $\mathrm{x}$ & $\mathrm{x}$ & $\mathrm{x}$ & $\mathrm{x}$ & $\mathrm{x}$ & $\mathrm{x}$ \\
\hline & & Global & $\begin{array}{l}\text { TR- } \\
\text { FRI1 }\end{array}$ & $\begin{array}{l}\text { TR- } \\
\text { FRI2 }\end{array}$ & $\begin{array}{c}\text { TR- } \\
\text { FRI3 }\end{array}$ & $\begin{array}{l}\text { TR- } \\
\text { FRI4 }\end{array}$ & TR-FRI5 \\
\hline & K & 10 & 7 & 6 & 7 & 6 & 7 \\
\hline & TSF & Lglat & & & & & \\
\hline
\end{tabular}

Least Flycatcher (LEFL)

A priori selected variables are in bold text.

\begin{tabular}{|c|c|c|c|c|c|c|c|}
\hline & & global & \multicolumn{5}{|c|}{ Tree density+FRI+ecosite+landscape } \\
\hline Subset & Var & & & & & & \\
\hline \multirow[t]{5}{*}{ Treeden } & supcan & $\mathrm{x}$ & $\mathrm{x}$ & & & $\mathrm{x}$ & $\mathrm{x}$ \\
\hline & medlpin & $\mathrm{x}$ & & & & & \\
\hline & conba & & & & & & \\
\hline & deciba & $\mathrm{x}$ & $\mathrm{x}$ & & $\mathrm{x}$ & $\mathrm{x}$ & $\mathrm{x}$ \\
\hline & totalba & $\mathrm{x}$ & & $\mathrm{x}$ & $\mathrm{x}$ & & $\mathrm{x}$ \\
\hline FRI & fixage & $\mathrm{x}$ & $\mathrm{x}$ & & $\mathrm{x}$ & & \\
\hline Ecosite & ecosite & $\mathrm{x}$ & & $\mathrm{x}$ & $\mathrm{x}$ & $\mathrm{x}$ & \\
\hline Landscape & mps & $\mathrm{x}$ & & & & & $\mathrm{x}$ \\
\hline \multirow[t]{4}{*}{ Spatial } & trend surface & $\mathrm{x}$ & $\mathrm{x}$ & $\mathrm{x}$ & $\mathrm{x}$ & $\mathrm{x}$ & $\mathrm{x}$ \\
\hline & & Global & $\begin{array}{c}\text { TR- } \\
\text { FRI1 }\end{array}$ & $\begin{array}{c}\text { TR- } \\
\text { FRI2 }\end{array}$ & $\begin{array}{c}\text { TR- } \\
\text { FRI3 }\end{array}$ & $\begin{array}{c}\text { TR- } \\
\text { FRI4 }\end{array}$ & TR-FRI5 \\
\hline & $\mathrm{K}$ & 12 & 8 & 7 & 9 & 8 & 9 \\
\hline & TSF & latcorr, $\lg$ & $\lg 2$ & & & & \\
\hline
\end{tabular}

Northern Parula Warbler (NPWA)

A priori selected variables are in bold text.

\begin{tabular}{|l|l|c|c|c|c|c|c|}
\hline & & global & \multicolumn{5}{|c|}{ Tree density+FRI+ecosite+landscape } \\
\hline Subset & Var & & & & & & \\
\hline Treeden & supcan & $\mathrm{x}$ & $\mathrm{x}$ & $\mathrm{x}$ & & $\mathrm{x}$ & $\mathrm{x}$ \\
\hline & medlpin & $\mathrm{x}$ & & & & $\mathrm{x}$ & \\
\hline & conba & $\mathrm{x}$ & $\mathrm{x}$ & $\mathrm{x}$ & $\mathrm{x}$ & & \\
\hline & deciba & $\mathrm{x}$ & & $\mathrm{x}$ & $\mathrm{x}$ & & $\mathrm{x}$ \\
\hline & totalba & $\mathrm{x}$ & $\mathrm{x}$ & & & $\mathrm{x}$ & \\
\hline & & & & & & & \\
\hline FRI & fixage & $\mathrm{x}$ & $\mathrm{x}$ & $\mathrm{x}$ & & $\mathrm{x}$ & \\
\hline Ecosite & ecosite & $\mathrm{x}$ & & & $\mathrm{x}$ & & \\
\hline Landscape & mps & $\mathrm{x}$ & & & & & $\mathrm{x}$ \\
\hline
\end{tabular}




\begin{tabular}{|c|c|c|c|c|c|c|c|}
\hline Spatial & trend surface & $\mathrm{x}$ & $x$ & $\mathrm{X}$ & $\mathrm{x}$ & $\mathrm{X}$ & $\mathrm{x}$ \\
\hline & & Global & $\begin{array}{l}\text { TR- } \\
\text { FRI1 }\end{array}$ & $\begin{array}{l}\text { TR- } \\
\text { FRI2 }\end{array}$ & $\begin{array}{c}\text { TR- } \\
\text { FRI3 }\end{array}$ & $\begin{array}{c}\text { TR- } \\
\text { FRI4 }\end{array}$ & TR-FRI5 \\
\hline & $\begin{array}{r}\mathrm{r} \\
\mathrm{TS}\end{array}$ & $\begin{array}{c}11 \\
\text { corr }\end{array}$ & 7 & 7 & 6 & 7 & 6 \\
\hline
\end{tabular}

Pine Warbler (PIWA)

A priori selected variables are in bold text.

\begin{tabular}{|c|c|c|c|c|c|c|c|}
\hline \multirow[b]{2}{*}{ Subset } & \multirow[b]{2}{*}{ Var } & \multirow[t]{2}{*}{ global } & \multicolumn{5}{|c|}{ Tree density+FRI+ecosite+landscape } \\
\hline & & & & & & & \\
\hline \multirow[t]{5}{*}{ Treeden } & supcan & $\mathrm{x}$ & $\mathrm{x}$ & $\mathrm{x}$ & & $\mathrm{x}$ & $\mathrm{x}$ \\
\hline & medlpin & $\mathrm{x}$ & & $\mathrm{x}$ & $\mathrm{x}$ & & \\
\hline & conba & & & & & & \\
\hline & deciba & & & & & & \\
\hline & totalba & $\mathrm{x}$ & $\mathrm{x}$ & & & $\mathrm{x}$ & \\
\hline FRI & fixage & $\mathrm{x}$ & $\mathrm{x}$ & & $\mathrm{x}$ & & $\mathrm{x}$ \\
\hline Ecosite & ecosite & $\mathrm{x}$ & & $\mathrm{x}$ & $\mathrm{x}$ & $\mathrm{x}$ & \\
\hline Landscape & mps & $\mathrm{x}$ & & & & & $\mathrm{x}$ \\
\hline \multirow{3}{*}{ Spatial } & trend surface & $\mathrm{x}$ & $\mathrm{x}$ & $\mathrm{x}$ & $\mathrm{x}$ & $\mathrm{x}$ & $\mathrm{x}$ \\
\hline & & Global & $\begin{array}{l}\text { TR- } \\
\text { FRI1 }\end{array}$ & $\begin{array}{l}\text { TR- } \\
\text { FRI2 }\end{array}$ & $\begin{array}{l}\text { TR- } \\
\text { FRI3 }\end{array}$ & $\begin{array}{l}\text { TR- } \\
\text { FRI4 }\end{array}$ & TR-FRI5 \\
\hline & $\begin{array}{r}\mathrm{K} \\
\mathrm{TSF}\end{array}$ & $\begin{array}{c}10 \\
\text { latcorr, lat2 }\end{array}$ & 7 & 7 & 7 & 7 & 7 \\
\hline
\end{tabular}

Pileated Woodpecker (PIWO)

A priori selected variables are in bold text.

\begin{tabular}{|c|c|c|c|c|c|c|c|}
\hline \multirow[b]{2}{*}{ Subset } & \multirow[b]{2}{*}{ Var } & \multirow[t]{2}{*}{ global } & \multicolumn{5}{|c|}{ Tree density+FRI+ecosite+landscape } \\
\hline & & & & & & & \\
\hline \multirow[t]{5}{*}{ Treeden } & supcan & $\mathrm{x}$ & $\mathrm{x}$ & $\mathrm{x}$ & & $\mathrm{x}$ & $\mathrm{x}$ \\
\hline & medlpin & $\mathrm{x}$ & & & & $\mathrm{x}$ & \\
\hline & conba & $\mathrm{x}$ & & $\mathrm{x}$ & $\mathrm{x}$ & & $\mathrm{x}$ \\
\hline & deciba & $\mathrm{x}$ & & & $\mathrm{x}$ & & \\
\hline & totalba & $\mathrm{x}$ & $\mathrm{x}$ & & & & $\mathrm{x}$ \\
\hline FRI & fixage & $\mathrm{x}$ & & $\mathrm{x}$ & & $\mathrm{x}$ & $\mathrm{x}$ \\
\hline Ecosite & ecosite & $\mathrm{x}$ & $\mathrm{x}$ & & $\mathrm{x}$ & $\mathrm{x}$ & \\
\hline Landscape & mps & $x$ & & & & & $\mathrm{x}$ \\
\hline \multirow[t]{4}{*}{ Spatial } & trend surface & & & & & & \\
\hline & & Global & $\begin{array}{l}\text { TR- } \\
\text { FRI1 }\end{array}$ & $\begin{array}{l}\text { TR- } \\
\text { FRI2 }\end{array}$ & $\begin{array}{l}\text { TR- } \\
\text { FRI3 }\end{array}$ & $\begin{array}{c}\text { TR- } \\
\text { FRI4 }\end{array}$ & TR-FRI5 \\
\hline & $\mathrm{K}$ & 10 & 5 & 5 & 5 & 6 & 7 \\
\hline & TSF & - & & & & & \\
\hline
\end{tabular}


Red-breasted Nuthatch (RBNU)

A priori selected variables are in bold text.

\begin{tabular}{|c|c|c|c|c|c|c|c|}
\hline & & global & \multicolumn{5}{|c|}{ Tree density+FRI+ecosite+landscape } \\
\hline Subset & Var & & & & & & \\
\hline \multirow[t]{5}{*}{ Treeden } & supcan & $\mathrm{x}$ & & $\mathrm{x}$ & & $\mathrm{x}$ & \\
\hline & medlpin & $\mathrm{x}$ & & $\mathrm{x}$ & $\mathrm{x}$ & & $\mathrm{x}$ \\
\hline & conba & $\mathrm{x}$ & $\mathrm{x}$ & & $\mathrm{x}$ & $\mathrm{x}$ & $\mathrm{x}$ \\
\hline & deciba & & & & & & \\
\hline & totalba & $\mathrm{x}$ & $\mathrm{x}$ & $\mathrm{x}$ & $\mathrm{x}$ & & \\
\hline FRI & fixage & $\mathrm{x}$ & & $\mathrm{x}$ & $\mathrm{x}$ & & $\mathrm{X}$ \\
\hline Ecosite & ecosite & $\mathrm{x}$ & $\mathrm{x}$ & $\mathrm{x}$ & & $\mathrm{x}$ & \\
\hline Landscape & mps & $\mathrm{x}$ & & & & & $X$ \\
\hline \multirow{3}{*}{ Spatial } & trend surface & $\mathrm{x}$ & $\mathrm{x}$ & $\mathrm{x}$ & $\mathrm{x}$ & $\mathrm{x}$ & $X$ \\
\hline & & Global & $\begin{array}{l}\text { TR- } \\
\text { FRI1 }\end{array}$ & $\begin{array}{l}\text { TR- } \\
\text { FRI2 }\end{array}$ & $\begin{array}{l}\text { TR- } \\
\text { FRI3 }\end{array}$ & $\begin{array}{c}\text { TR- } \\
\text { FRI4 }\end{array}$ & TR-FRI5 \\
\hline & $\begin{array}{r}\mathrm{K} \\
\mathrm{TSF}\end{array}$ & $\begin{array}{c}11 \\
\text { lgcorr, lat2 }\end{array}$ & 7 & 9 & 8 & 7 & 8 \\
\hline
\end{tabular}

Winter Wren (WIWR)

A priori selected variables are in bold text.

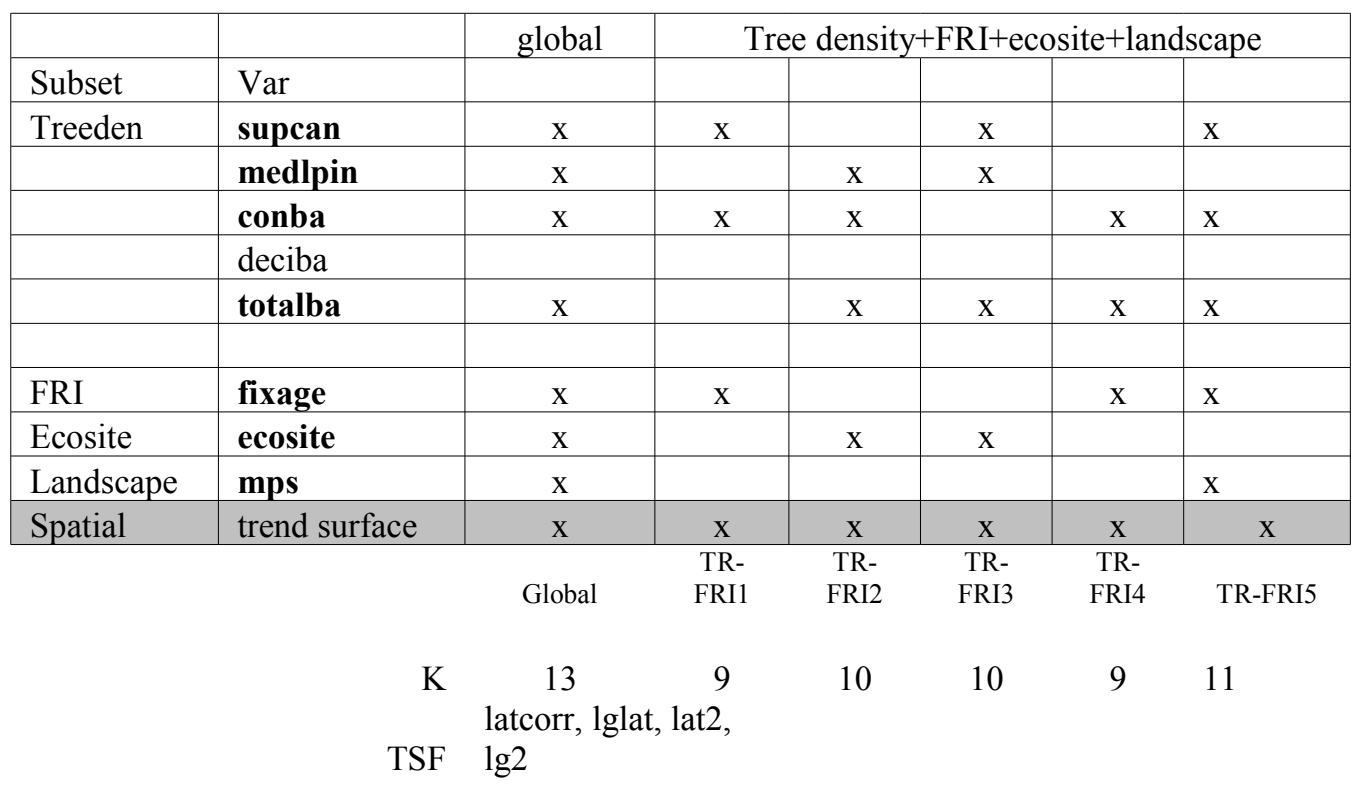

Species richness

A priori selected variables are in bold text.

\begin{tabular}{|l|l|c|c|c|c|c|c|}
\hline & & global & \multicolumn{4}{|c|}{ Tree density+FRI+ecosite+landscape } \\
\hline Subset & Var & & & & & \\
\hline Treeden & supcan & $\mathrm{x}$ & $\mathrm{x}$ & $\mathrm{x}$ & & $\mathrm{x}$ & \\
\hline & medlpin & $\mathrm{x}$ & & $\mathrm{x}$ & & & $\mathrm{x}$ \\
\hline
\end{tabular}




\begin{tabular}{|c|c|c|c|c|c|c|c|}
\hline & conba & $\mathrm{x}$ & & & $\mathrm{x}$ & $\mathrm{x}$ & \\
\hline & deciba & $\mathrm{x}$ & & & $\mathrm{x}$ & $\mathrm{x}$ & $\mathrm{x}$ \\
\hline & totalba & $\mathrm{x}$ & & $\mathrm{x}$ & & & \\
\hline FRI & fixage & $\mathrm{x}$ & $\mathrm{x}$ & & $\mathrm{x}$ & & $\mathrm{x}$ \\
\hline Ecosite & ecosite & $\mathrm{x}$ & & $\mathrm{x}$ & & $\mathrm{x}$ & \\
\hline Landscape & mps & $\mathrm{x}$ & & & & & $\mathrm{x}$ \\
\hline Spatial & trend surface & & & & & & \\
\hline & & Global & $\begin{array}{l}\text { TR- } \\
\text { FRI1 }\end{array}$ & $\begin{array}{c}\text { TR- } \\
\text { FRI2 }\end{array}$ & $\begin{array}{c}\text { TR- } \\
\text { FRI3 }\end{array}$ & $\begin{array}{l}\text { TR- } \\
\text { FRI4 }\end{array}$ & TR-FRI5 \\
\hline & $\begin{array}{r}\mathrm{K} \\
\mathrm{TSF}\end{array}$ & 10 & 4 & 6 & 5 & 6 & 6 \\
\hline
\end{tabular}

Abundance

A priori selected variables are in bold text.

\begin{tabular}{|c|c|c|c|c|c|c|c|}
\hline & & global & \multicolumn{5}{|c|}{ Tree density+FRI+ecosite+landscape } \\
\hline Subset & Var & & & & & & \\
\hline \multirow[t]{5}{*}{ Treeden } & supcan & $\mathrm{x}$ & $\mathrm{x}$ & $\mathrm{x}$ & & $\mathrm{x}$ & \\
\hline & medlpin & $\mathrm{x}$ & & $\mathrm{x}$ & & & $\mathrm{x}$ \\
\hline & conba & $\mathrm{x}$ & & & $\mathrm{x}$ & $\mathrm{x}$ & \\
\hline & deciba & $\mathrm{x}$ & & & $\mathrm{x}$ & $\mathrm{x}$ & $\mathrm{x}$ \\
\hline & totalba & $\mathrm{x}$ & & $\mathrm{x}$ & & & \\
\hline FRI & fixage & $\mathrm{x}$ & $\mathrm{x}$ & & $\mathrm{x}$ & & $\mathrm{x}$ \\
\hline Ecosite & ecosite & $\mathrm{x}$ & & $\mathrm{x}$ & & $\mathrm{x}$ & \\
\hline Landscape & mps & $\mathrm{x}$ & & & & & $\mathrm{x}$ \\
\hline Spatial & trend surface & $\mathrm{x}$ & $\mathrm{x}$ & $\mathrm{x}$ & $\mathrm{x}$ & $\mathrm{x}$ & $\mathrm{x}$ \\
\hline & & Global & $\begin{array}{l}\text { TR- } \\
\text { FRI1 }\end{array}$ & $\begin{array}{l}\text { TR- } \\
\text { FRI2 }\end{array}$ & $\begin{array}{l}\text { TR- } \\
\text { FRI3 }\end{array}$ & $\begin{array}{l}\text { TR- } \\
\text { FRI4 }\end{array}$ & TR-FRI \\
\hline
\end{tabular}

$\begin{array}{llllllll}\mathrm{K} & 12 & 6 & 8 & 7 & 8 & 8\end{array}$

TSF latcorr, $\lg 2$ 
Appendix 2. Comparison of avian abundance between old-growth pine stands ( $>130$ years old) and younger pine stands, controlling for spatial autocorrelation. Each territorial male was originally counted as two individuals. As this may not be valid, all counts were divided by two and rounded to whole integers. Light shade shows species significantly more abundant in old-growth stands. Dark shade shows species significantly more abundant in younger stands.

\begin{tabular}{|c|c|c|c|c|c|c|c|c|c|}
\hline & Old growth stands ${ }^{1}$ & $\begin{array}{r}\text { Younger } \\
\text { stands }\end{array}$ & Model $^{2}$ & Coefficient $^{3}$ & s.e. & $\mathrm{Z}$ & $\mathrm{P}>/ \mathrm{Z} /$ & $\mathrm{IRR}^{4}$ & Trend surface ${ }^{5}$ \\
\hline American robin Turdus migratorius (AMRO) & $0.36 \pm 0.17$ & $1.03 \pm 0.29$ & $\mathrm{nb}$ & -0.53 & $\begin{array}{r}0.6 \\
9 \\
0.5\end{array}$ & -0.76 & 0.44 & & lglat, lgcorr \\
\hline Black-and-white warbler Mniotilta varia (BAWW) & $2.50 \pm 0.45$ & $1.68 \pm 0.28$ & 1 & 0.76 & $\begin{array}{r}5 \\
0.5\end{array}$ & 1.39 & 0.17 & & lat2 \\
\hline Bay-breasted warbler Setophaga castanea (BBWA) & $0.64 \pm 0.27$ & $0.53 \pm 0.26$ & $\mathrm{p}$ & 0.90 & 5 & 1.63 & 0.10 & & latcorr, $\lg 2$ \\
\hline Black-capped chickadee Poecile atricapillus $(\mathrm{BCCH})$ & $0.57 \pm 0.25$ & $1.53 \pm 0.26$ & $\mathrm{nb}$ & -1.06 & $\begin{array}{r}0.4 \\
5\end{array}$ & -2.34 & 0.02 & 0.34 & Lglat \\
\hline Blue-headed vireo Vireo solitarius (BHVI) & $1.43 \pm 0.31$ & $1.21 \pm 0.26$ & 1 & 0.16 & $\begin{array}{r}0.4 \\
6 \\
1.0\end{array}$ & 0.35 & 0.73 & & latcorr, lgcorr \\
\hline Blackburnian warbler Setophaga fusca (BLBW) & $8.86 \pm 0.78$ & $6.26 \pm 0.66$ & 1 & 1.94 & $\begin{array}{r}7 \\
0.3\end{array}$ & 1.82 & 0.08 & & $\lg 2, \operatorname{lgcorr}$ \\
\hline Blue jay Cyanocitta cristata (BLJA) & $1.50 \pm 0.37$ & $1.18 \pm 0.24$ & $\mathrm{nb}$ & 0.20 & 2 & 0.62 & 0.54 & & $\lg 2$ \\
\hline Brown creeper Certhia americana (BRCR) & $2.71 \pm 0.65$ & $1.61 \pm 0.22$ & $\mathrm{p}$ & 0.42 & $\begin{array}{r}0.2 \\
1\end{array}$ & 2.00 & 0.05 & 1.52 & lat2 \\
\hline $\begin{array}{l}\text { Black-throated blue warbler Setophaga caerulesecens } \\
\text { (BTBW) }\end{array}$ & $1.79 \pm 0.66$ & $1.71 \pm 0.31$ & $\mathrm{nb}$ & 0.12 & $\begin{array}{r}0.3 \\
0 \\
1.0\end{array}$ & 0.41 & 0.69 & & $\lg 2$ \\
\hline Black-throated green warbler Setophaga virens (BTNW) & $6.07 \pm 0.74$ & $4.37 \pm 0.60$ & 1 & 1.52 & $\begin{array}{r}6 \\
0.4\end{array}$ & 1.44 & 0.16 & & $\lg 2$, lgcorr \\
\hline Canada warbler Cardellina canadensis (CAWA) & $0.71 \pm 0.27$ & $0.68 \pm 0.18$ & $\mathrm{nb}$ & 0.04 & $\begin{array}{r}8 \\
0.8\end{array}$ & 0.09 & 0.93 & & - \\
\hline Cedar waxwing Bombycilla cedrorum (CEDW) & $0.21 \pm 0.11$ & $0.66 \pm 0.23$ & $\mathrm{nb}$ & -0.53 & 6 & -0.62 & 0.54 & & lglat,lg2,lat2 \\
\hline Chipping sparrow Spizella passerina (CHSP) & $0.43 \pm 0.20$ & $0.79 \pm 0.26$ & $\mathrm{p}$ & -1.12 & $\begin{array}{r}0.4 \\
5\end{array}$ & -2.50 & 0.01 & 0.32 & lgcorr \\
\hline Common raven Corvus corax (CORA) & $0.64 \pm 0.57$ & $0.42 \pm 0.14$ & $\mathrm{p}$ & 0.51 & $\begin{array}{r}0.4 \\
2 \\
0.8\end{array}$ & 1.21 & 0.23 & & lglat \\
\hline Chestnut-sided warbler Setophaga pensylvanica (CSWA) & $0.64 \pm 0.37$ & $1.16 \pm 0.41$ & $\mathrm{nb}$ & -0.02 & $\begin{array}{r}3 \\
0.6\end{array}$ & -0.02 & 0.98 & & $\lg 2$ \\
\hline Downy woodpecker Picoides pubescens (DOWO) & $0.29 \pm 0.16$ & $0.34 \pm 0.12$ & $\mathrm{p}$ & -0.18 & $\begin{array}{r}1 \\
0.7\end{array}$ & -0.29 & 0.77 & & lglat, lgcorr,lat2, lg2 \\
\hline Eastern wood-pewee Contopus virens (EWPE) & $0.86 \pm 0.31$ & $1.34 \pm 0.38$ & $\mathrm{nb}$ & -0.18 & $\begin{array}{r}4 \\
0.4\end{array}$ & -0.24 & 0.81 & & - \\
\hline Evening grosbeak Coccothraustes vespertinus (EVGR) & $1.43 \pm 0.76$ & $0.61 \pm 0.13$ & $\mathrm{nb}$ & 0.60 & $\begin{array}{r}5 \\
0.5\end{array}$ & 1.33 & 0.18 & & lglat \\
\hline Golden-crowned kinglet Regulus satrapa (GCKI) & $2.14 \pm 0.50$ & $1.87 \pm 0.27$ & 1 & 0.17 & 0 & 0.35 & 0.73 & & lglat \\
\hline
\end{tabular}


Hairy woodpecker Picoides villosus (HAWO)

Hermit thrush Catharus guttatus (HETH)

Least flycatcher Empidonax minimus (LEFL)

Magnolia warbler Setophaga magnolia (MAWA)

Nashville warbler Oreothlypis ruficapilla (NAWA)

Northern flicker Colaptes auratus (NOFL)

Northern parula Setophaga americana (NPWA)

Ovenbird Seiurus aurocapilla (OVEN)

Pine warbler Setophaga pinus (PIWA)

Pileated woodpecker Dryocopus pileatus (PIWO)

Purple finch Carpodacus purpureus (PUFI)

Rose-breasted grosbeak Pheucticus ludovicianus (RBGR)

Red-breasted nuthatch Sitta canadensis (RBNU)

Ruby-crowned kinglet Regulus calendula (RCKI)

Red-eyed vireo Vireo olivaceus (REVI)

Ruffed grouse Bonasa umbellus (RUGR)

Scarlet tanager Piranga olivacea (SCTA)

Swainson's thrush Catharus ustulatus (SWTH)

Veery Catharus fuscescens (VEER)

Winter wren Troglodytes hiemalis (WIWR)

White-throated sparrow Zonotrichia albicollis (WTSP)

Yellow-bellied flycatcher Empidonax flaviventris (YBFL)

Yellow-bellied sapsucker Sphyrapicus varius (YBSA)

\begin{tabular}{|c|c|c|c|c|c|c|c|c|}
\hline $0.57 \pm 0.31$ & $0.61 \pm 0.14$ & $\mathrm{nb}$ & -0.06 & $\begin{array}{r}0.5 \\
1 \\
0.4\end{array}$ & -0.11 & 0.91 & & - \\
\hline $1.36 \pm 0.63$ & $2.84 \pm 0.49$ & $\mathrm{nb}$ & -0.36 & $\begin{array}{r}0 \\
0.4\end{array}$ & -0.89 & 0.37 & & lglat, lg2, lat2 \\
\hline $2.79 \pm 0.57$ & $2.16 \pm 0.59$ & $\mathrm{nb}$ & 0.40 & $\begin{array}{r}5 \\
0.1\end{array}$ & 0.89 & 0.37 & & latcorr, lgcorr, lg2 \\
\hline $4.79 \pm 0.77$ & $4.61 \pm 0.69$ & $\mathrm{nb}$ & -0.19 & $\begin{array}{r}9 \\
0.2\end{array}$ & -1.03 & 0.31 & & latcorr, lglat, lat2, $\lg 2$ \\
\hline $\begin{array}{l}2.64 \pm 0.63 \\
0.29 \pm 0.16\end{array}$ & $\begin{array}{l}3.47 \pm 0.43 \\
0.47 \pm 0.12\end{array}$ & $\mathrm{nb}$ & $\begin{array}{l}-0.26 \\
-0.46\end{array}$ & $\begin{array}{r}3 \\
0.5 \\
8\end{array}$ & $\begin{array}{l}-1.12 \\
-0.79\end{array}$ & 0.26 & & $\begin{array}{l}\text { latcorr, lgcorr } \\
\lg 2, \text { lgcorr, lat2 }\end{array}$ \\
\hline $1.50 \pm 0.54$ & $0.18 \pm 0.08$ & $\mathrm{p}$ & 1.52 & $\begin{array}{r}0.4 \\
4\end{array}$ & 3.48 & 0.00 & 4.58 & lgcorr \\
\hline $13.00 \pm 1.31$ & $13.34 \pm 0.71$ & 1 & -0.25 & $\begin{array}{r}1.3 \\
7 \\
0.2\end{array}$ & -0.18 & 0.86 & & $\lg 2$, lglat, lat2 \\
\hline $3.07 \pm 0.79$ & $2.21 \pm 0.34$ & $\mathrm{nb}$ & 0.43 & $\begin{array}{r}8 \\
0.4\end{array}$ & 1.52 & 0.13 & & latcorr, lat2 \\
\hline $1.21 \pm 0.39$ & $0.95 \pm 0.22$ & $\mathrm{nb}$ & 0.25 & $\begin{array}{r}1 \\
0.7\end{array}$ & 0.60 & 0.55 & & - \\
\hline $0.21 \pm 0.11$ & $0.47 \pm 0.15$ & $\mathrm{nb}$ & -0.79 & $\begin{array}{r}6 \\
0.6\end{array}$ & -1.04 & 0.30 & & - \\
\hline $0.29 \pm 0.16$ & $0.82 \pm 0.20$ & $\mathrm{nb}$ & -0.54 & $\begin{array}{r}6 \\
0.1\end{array}$ & -0.83 & 0.41 & & $\lg 2, \operatorname{lgcorr}$ \\
\hline $3.07 \pm 0.37$ & $2.74 \pm 0.32$ & $\mathrm{p}$ & -0.14 & $\begin{array}{r}9 \\
0.4\end{array}$ & -0.76 & 0.45 & & lat2, lgcorr \\
\hline $0.57 \pm 0.25$ & $0.82 \pm 0.34$ & $\mathrm{p}$ & 0.03 & $\begin{array}{r}3 \\
0.1\end{array}$ & 0.08 & 0.94 & & latcorr, lgcorr \\
\hline $8.93 \pm 0.68$ & $8.00 \pm 0.52$ & $\mathrm{p}$ & 0.11 & $\begin{array}{r}1 \\
0.4\end{array}$ & 1.03 & 0.30 & & - \\
\hline $0.86 \pm 0.23$ & $0.84 \pm 0.23$ & $\mathrm{nb}$ & -0.02 & $\begin{array}{r}1 \\
0.4\end{array}$ & -0.04 & 0.97 & & latcorr, lg2 \\
\hline $1.07 \pm 0.35$ & $0.58 \pm 0.15$ & $\mathrm{p}$ & 0.99 & 2 & 2.34 & 0.02 & 2.69 & latcorr, lglat, lat2, $\lg 2$ \\
\hline $7.21 \pm 0.50$ & $5.89 \pm 0.76$ & 1 & -0.23 & $\begin{array}{r}0.9 \\
5 \\
0.4\end{array}$ & -0.25 & 0.81 & & lgcorr, $\lg 2$ \\
\hline $1.29 \pm 0.46$ & $2.74 \pm 0.49$ & $\mathrm{nb}$ & -0.61 & $\begin{array}{r}3 \\
0.7\end{array}$ & -1.42 & 0.16 & & lgcorr \\
\hline $5.00 \pm 0.62$ & $3.21 \pm 0.49$ & 1 & 1.30 & $\begin{array}{r}8 \\
0.2\end{array}$ & 1.68 & 0.10 & & latcorr, lglat, lat2, lg2 \\
\hline $4.00 \pm 0.75$ & $3.50 \pm 0.49$ & $\mathrm{nb}$ & 0.03 & $\begin{array}{r}5 \\
0.6\end{array}$ & 0.11 & 0.91 & & lat2 \\
\hline $0.36 \pm 0.20$ & $0.89 \pm 0.31$ & $\mathrm{nb}$ & -0.63 & $\begin{array}{r}3 \\
0.3\end{array}$ & -1.01 & 0.31 & & latcorr, lgcorr \\
\hline $1.36 \pm 0.49$ & $2.45 \pm 0.37$ & $\mathrm{nb}$ & -0.28 & 3 & -0.85 & 0.39 & & $\lg 2$, lglat \\
\hline
\end{tabular}


Total species richness

\section{Plus raptors}

Minus raptors

Total species abundance

\section{Plus raptors}

Minus raptors

Migratory status

Short distance migrants

Neotropical migrants

Resident

Nomadic

'Numbers shown mean + SE

${ }^{2}$ Poisson (p), negative binomial (nb) or linear regressions (l)

${ }^{3}$ Positive or negative coefficients indicate higher or lower abundances in old growth than younger stands, respectively.

${ }^{4}$ Incidence rate ratios (IRR) for probability distributions are shown for significant relationships between species abundance and old growth stands.

${ }^{5}$ Significant trend surface variables derived from forward selection.

\section{$26.64 \pm 0.87$}

$26.55 \pm 0.62$

$26.50 \pm 0.85$

$26.03 \pm 0.59$

$101.07 \pm 4.71$

$94.18 \pm 3.18$

$100.43 \pm 4.58$

$93.29 \pm 3.20$

$7.71 \pm 0.42$

$8.74 \pm 0.31$ $14.93 \pm 0.55$

$13.50 \pm 0.44$

$3.43 \pm 0.39$

$3.71 \pm 0.25$

$0.68 \pm 0.13$

$\mathrm{p}$

\begin{tabular}{rr}
0.4 & -0.52 \\
\hline
\end{tabular} 